Universidade de São Paulo

Instituto de Física de São Carlos

Guilherme da Costa Pereira Innocentini

Modelamento estocástico para a expressão gênica

São Carlos 
Guilherme da Costa Pereira Innocentini

\section{Modelamento estocástico para a expressão gênica}

Dissertação apresentada ao Instituto de Física de São Carlos da Universidade de São Paulo para obtenção do título de Mestre em Ciências: Física Básica.

Área de concentração: biofísica, estatística.

Orientador: José Eduardo Martinho Hornos

São Carlos 



\section{Agradecimentos}

Agradeço aos professores e funcionários do Instituto de Física de São Carlos onde me graduei e realizei este trabalho. À Coordenação de Aperfeiçoamento de Pessoal de Nível Superior (CAPES) que apoiou financeiramente este trabalho. Aos meus pais, Lourenço Innocentini Neto e Cristina Helena da C.P. Innocentini, que sempre estiveram amorosamente ao meu lado, me apoiando e me educando. À Ana Carolina C. Parra pelo carinho e compreensão. Aos meus amigos Gilberto Medeiros Nakamura, Marco Alberto Perez e William Couto Corrêa de Lima pelas boas e inspiradoras conversas que tivemos. Ao Marcel Orlandi Paiano, grande amigo e companheiro de aventuras nas "Pasárgadas" da vida. Por último, ao meu orientador Prof. José Eduardo Martinho Hornos, pela orientação, pelos ensinamentos e, acima de tudo, pela amizade e confiança. 


\section{Resumo}

Innocentini G.C.P. Modelamento estocástico para a expressão gênica. 2008. 53 p. Dissertação (Mestrado) - Instituto de Física de São Carlos, Universidade de São Paulo, São Carlos, 2008.

Nesta dissertação consideramos um o modelo para um gene como sendo um sistema de dois estados, tipo spin, e apresentamos um modelo estocástico para a expressão gênica. As soluções estacionárias e, também, as dependentes do tempo, para o processo de transcrição, são obtidas e as distribuições de probabilidade, que descrevem o estado funcional do gene, são calculadas analiticamente. O valor médio e o ruído transcricional na população de mRNA são analisados. O efeito do ruído transcricional na síntese proteica é contemplado acoplando-se os processo de transcrição e tradução.

Palavras-chave: expressão gênica, ruído, regulação transcricional, estocasticidade. 


\begin{abstract}
Innocentini G.C.P. Modeling stochastic gene expression. 2008. 53 p. Thesis (Master) - Instituto de Física de São Carlos, Universidade de São Paulo, São Carlos, 2008.

In this dissertation we present a two state stochastic model, spin-like, for gene expression. The steady-state solutions and also the time-dependente solutions for the transcription are probed and the probability distribution functions, which describe the functional state of the gene, are exactly calculated. The mean value and the transcriptional noise in the mRNA population are analyzed. The effects of the transcriptional noise in the protein synthesis are contemplated by coupling the transcription and the translation.
\end{abstract}

Keywords: gene expression, noise, transcriptional regulation, stochasticiy. 


\section{Sumário}

1 Introdução

2 O modelo para expressão gênica

3 Propriedades assintóticas do processo transcricional

3.1 As equacões e suas solucões estacionárias para a transcrição . . . . . . . . 17

3.2 O conteúdo biológico do modelo . . . . . . . . . . . . . . . . . . . . . . 19

3.3 Valores médios e ruído . . . . . . . . . . . . . . . . . . . . . 22

3.4 Probabilidades . . . . . . . . . . . . . . . . . . . 25

4 Dinâmica transcricional $\quad 29$

4.1 A solucão dependente do tempo . . . . . . . . . . . . . . . . . . . . . . 29

4.2 Valor médio e ruído dependentes do tempo . . . . . . . . . . . . . . . . . 34

4.3 Probabilidades dependentes do tempo . . . . . . . . . . . . . . . . . . 36

5 O efeito do ruído transcricional na síntese proteica 43

$\begin{array}{lll}6 & \text { Conclusões } & 49\end{array}$

Referências $\quad 51$ 


\section{Capítulo 1}

\section{Introdução}

A expressão gênica é o processo no qual a informação codificada em um gene é descodificada em uma proteína específica. Em um dado instante de sua vida, cada célula usa apenas um subconjunto de genes para a produção de outras moléculas, estes genes que são expressos são ditos ligados e os que não são expressos desligados. O ligamento e o desligamento de genes é uma propriedade fundamental dos processos biológicos.

Na década de 50, André Lwoff e seus colegas, François Jacob e Jacques Monod, do Instituto Pasteur observaram [1] que certa classe da bactéria Escherichia coli quando irradiada com doses moderadas de luz ultravioleta, paravam de crescer e aproximadamente 90 minutos mais tarde ocorria o rompimento das bactérias (lise) e uma quantidade de vírus, chamados de $\lambda$-phage, eram liberados no meio. Os vírus se multiplicavam infectando novas bactérias. Logo estas bactérias infectadas rompiam-se e novos vírus eram liberados. No entanto, algumas bactérias infectadas sobreviviam e carregavam o vírus em sua forma inativa. Essas bactérias cresciam e se dividiam normalmente até que a cultura era novamente irradiada e essas bactérias descendentes rompiam-se e liberavam uma nova quantidade de vírus no meio. André Lwoff e seus colegas chegaram à conclusão que esta alternância entre os dois estados do vírus - na forma inativa quando a bactéria está crescendo e se dividindo e a forma ativa quando a cultura é irradiada - é um simples exemplo do ligamento e desligamento dos genes.

Neste mesmo período, Monod observou, também em culturas da bactéria Escherichia 
coli, um fenômeno que ele batizou com o nome de diauxie. Neste, a cultura de bactéria é colocada para crescer em um meio composto por diversas fontes de açúcar (glicose e lactose, por exemplo). Monod constatou que a cultura crescia em dois estágios e que entre um estágio e outro havia um lapso de tempo em que a população de bactérias permanecia inalterada. Na primeira fase de crescimento a cultura crescia consumindo a glicose disponível no meio e na segunda consumindo lactose. Este comportamento populacional da Escherichia coli foi a inspiração para Monod propor no ano de 1961 [2], com a colaboração de Jacob, um modelo para o controle da expressão gênica. Neste modelo, Monod e Jacob, propõem que a enzima que degrada a lactose ( $\beta$-galactosidase) é o produto da transcrição de um óperon (lac-óperon). Este óperon é regulado, negativamente, por um gene constitutivo que produz o repressor lacI. Quando no meio em que a bactéria se desenvolve não está presente a lactose, o lac-óperon encontra-se desligado com o repressor lacI em seu sítio operador. No entanto, quando a lactose está presente no meio, esta inativa o repressor e o óperon passa a ser expresso. Este comportamento do lac-óperon também é um exemplo do ligamento e desligamento dos genes.

Estas observações experimentais mostraram o papel crucial de proteínas reguladoras para o controle de redes genéticas e intensas investigações experimentais e teóricas [3,4, 5, 6, 1, 1, 8, 9, 10, 11, 12, 13] foram dedicadas para o entendimento destas redes gênicas.

Esta dissertação é dividida, como se segue: no Capítulo 2 um modelo estocástico para a expressão gênica é apresentado e discutido. No Capítulo 3 as propriedades assintóticas do modelo apresentado são obtidas e analisadas ressaltando a importância biológica dos parâmetros do modelo. No capítulo 4 as propriedades dinâmicas das quantidades estatísticas do modelo são obtidas. No Capítulo 5 o efeito do ruído, proveniente do processo de transcrição, na síntense proteica é abordado e os resultados experimentais obtidos por Pedraza e van Oudenaarden, [14, são reproduzidos. Finalmente, o último capítulo é dedicado as conclusões. 


\section{Capítulo 2}

\section{O modelo para expressão gênica}

Em muitos processos químicos, o número de reagentes envolvidos nas reações é grande comparado com suas variações durante um intervalo de tempo característico do sistema. Sendo assim, o número de partículas pode ser, aproximadamente, descrito por uma variável contínua. Neste caso, as características básicas do sistema podem ser obtidas considerando-se um conjunto de equações diferencias, em geral não lineares, no qual as variáveis dinâmicas são o número de partículas de cada espécie presente no sistema.

A unidade básica da vida, a célula, realiza milhares de transformações químicas simultaneamente. No entanto, o baixo número de moléculas de cada espécie presente na célula faz com que as flutuações moleculares sejam significativamente grandes e uma descrição determinística, para este sistema biológico, deixa de ser a mais adequada fazendo com que uma abordagem estocástica seja inevitável [15,[16]. A partir dessa consideração, duas estratégias podem ser adotadas. A primeira consiste na introdução de flutuações, via o mecanismo de Langevin, com a inclusão de uma perturbação estocástica dependente do tempo [17, 18, 19, 20,21], e a segunda, é a realização de simulações numéricas considerando o conjunto total de reações [15, 16, 4, na célula.

Por sua vez, nosso objetivo aqui, é apresentar uma terceira estratégia. Para tanto, propomos um modelo estocástico simples para um único gene sob a ação de agentes externos. Tal modelo, pode ser utilizado como um "building block" para se entender complexas redes de genes interagentes. 
As propriedades reguladoras de um gene dependem de dois fatores principais. O primeiro deles é o número e as propriedades químicas das regiões não codificadoras no DNA, chamadas de sítios operadores. A segunda é a abundância de proteínas controladoras que possuem afinidade química por estes sítios, cujo papel é reprimir ou estimular a ação da polimerase e, conseqüentemente, regular a atividade do gene. O exemplo mais simples é quando a região controladora do gene possui um único sítio operador regulado por apenas um tipo de proteína. Dessa forma, temos um sistema de dois estados: o operador está livre e a transcrição ocorre, ou o operador está ocupado, por uma proteína, e a transcrição é proibida ou parcialmente obstruída.

A popular noção de spin, se encaixa perfeitamente neste cenário. "Spin up" corresponde à configuração em que o operador está livre e "spin down" à configuração em que o operador está ocupado. Em geral, a região controladora admite um grande número de combinações envolvendo os sítios operadores e as proteínas reguladoras, o que nos leva a um sistema cuja região controladora admite várias configurações e portanto, nos deparamos com um sistema de muitos estados ou "altos spins". Este é o caso da $\lambda$-phage, composto por dois genes, três sítios operadores e oito configurações possíveis da região controladora.

Uma primeira classe de modelos é obtida quando o gene apresenta um único estado (uma única configuração da região controladora) e a transcrição é modelada por um processo de produção e degradação de mRNA a ser acoplado com um processo estocástico para a tradução [22,23]. O papel das flutuações, ou o ruído intrínseco, deste sistema é analisado a partir de uma interação amplificadora, codificada no acoplamento entre os processos de transcrição e tradução, que reproduz os observados "bursts" de proteínas na tradução [22,23].

Neste trabalho, adotou-se uma descrição estatística microscópica, para um único gene binário (dois estados), focando a atenção nas probabilidades $\alpha_{n, m}(t)$ e $\beta_{n, m}(t)$ de se encontrar o operador livre ou parcialmente reprimido, respectivamente, quando a célula apresenta $n$ moléculas de mRNA e $m$ moléculas de proteínas.

A principal tarefa é escrever equações, que contemplem tanto o processo de transcrição quanto o de tradução, para as quantidades $\alpha_{n, m}(t)$ e $\beta_{n, m}(t)$, levando-se em consideração 
as propriedades biofísicas do sistema. Utilizando-se as taxas de reação química para se construir um processo de Markov binário [24, 25, 26] e a estratégia do acoplamento amplificativo entre a transcrição e a tradução [22, 23], as desejadas equações para as quantidades $\alpha_{n, m}(t)$ e $\beta_{n, m}(t)$ são obtidas.

Destarte, o modelo resume-se a um processo de produção e degradação de dois estados acoplados para o gene, no qual o estado "up" representa transcrição livre enquanto o estado "down" representa transcrição reprimida por um agente externo (em contraposição com o caso auto-interagente [26]) a ser combinado a um segundo processo de Markov para a tradução.

O estado ligado ("up") corresponde à configuração do gene no qual o sítio operador encontra-se sem uma proteína repressiva ligada a ele. Neste caso, se a mRNA polimerase alcançar o sítio promotor a transcrição ocorre livremente. Por sua vez, no estado desligado o operador está ocupado por uma proteína repressiva bloqueando totalmente ou parcialmente a transcrição.

As variáveis estocásticas são os números $n$ e $m$ de mRNA e proteínas, respectivamente, e as probabilidades de encontrarmos o gene no estado ligado ou desligado são denotadas por $\alpha_{n, m}(t)$ e $\beta_{n, m}(t)$, respectivamente. As probabilidades obedecem às equações:

$$
\begin{aligned}
\frac{d \alpha_{n, m}(t)}{d t} & =k\left[\alpha_{n-1, m}(t)-\alpha_{n, m}(t)\right]+\rho\left[(n+1) \alpha_{n+1, m}(t)-n \alpha_{n, m}(t)\right] \\
& -h \alpha_{n, m}(t)+f \beta_{n, m}(t)+n k_{p}\left[\alpha_{n, m-1}(t)-\alpha_{n, m}(t)\right] \\
& +\rho_{p}\left[(m+1) \alpha_{n, m+1}(t)-m \alpha_{n, m}(t)\right]
\end{aligned}
$$

e

$$
\begin{aligned}
\frac{d \beta_{n, m}(t)}{d t} & =k \chi\left[\beta_{n-1, m}(t)-\beta_{n, m}(t)\right]+\rho\left[(n+1) \beta_{n+1, m}(t)-n \beta_{n, m}(t)\right] \\
& +h \alpha_{n, m}(t)-f \beta_{n, m}(t)+n k_{p}\left[\beta_{n, m-1}(t)-\beta_{n, m}(t)\right] \\
& +\rho_{p}\left[(m+1) \beta_{n, m+1}(t)-m \beta_{n, m}(t)\right] .
\end{aligned}
$$

Os dois primeiros termos na Eq. (2.1) contendo os parâmetros $k$ e $\rho$, são independentes de $m$ e descrevem um processo de produção e degradação para a população de mRNA. A taxa de produção, $k$, controla a magnitude da reação de transcrição e é independente de 
$n$ e $m$. A independência deste parâmetro com relação as variáveis aleatórias do modelo mostra que a produção de moléculas de mRNA não depende do número de mRNA na célula (independência de $n$ ) e como o sistema descrito pelas Eqs. (2.1) e (2.2) não é alto-interagente, as proteínas por ele codificadas não influenciarão o funcionamento do gene (independência de $m$ ). A taxa de degradação, $\rho$, leva em consideração a taxa de decaimento do mRNA. Na ausência de interações, $\left(h=f=k_{p}=\rho_{p}=0\right)$ a solução é uma distribuição de Poisson com valor médio $k / \rho$. As mesmas considerações são válidas para os dois primeiros termos da Eq. (2.2), no entanto, neste caso, a distribuição de Poisson, que emerge na ausência de interações, apresenta valor médio $\chi k / \rho$. Se $\chi=0$ a transcrição do gene é completamente obstruída. No entanto, pequenos valores deste parâmetro irão permitir que a transcrição ocorra, em taxas pequenas, mesmo na presença de proteínas repressoras. A introdução dos próximos dois termos, que são proporcionais à $h$ e $f$, acoplam as equações. Os parâmetros $h$ e $f$ controlam a eficiência repressora do switch. A capacidade de a proteína ligar-se ao sítio operador é codificada no parâmetro $h$ que é independente do número de proteínas $(m)$ produzidas pelo gene, mostrando que o sistema não é auto-regulado. No caso em que o gene é auto-regulado este parâmetro é uma função do número de proteínas produzida pelo gene [26]. A taxa com que a proteína desliga-se do sítio operador, reduzindo a eficiência da repressão, é $f$. Os dois últimos termos descrevem a ação da transcrição na síntese proteica. A taxa de produção, no processo de tradução, $k_{p}$, aparece multiplicada pelo número $n$ do mRNA, causando o efeito amplificativo na tradução. A taxa de degradação de proteínas é $\rho_{p}$. As condições de contorno sobre as distribuições de probabilidade nas Eq. (2.1) e Eq.(2.2) são $\alpha_{n, m}(t)=0$ e $\beta_{n, m}(t)=0$ para $n$ ou $m$ menores que zero, $\alpha_{n, m}(t)$ e $\beta_{n, m}(t)$ sejam positivas e convirjam para grandes valores de $n$ e $m$.

As Eq. (2.1) e Eq. (2.2) são equações do tipo diferencial-diferença e para resolvê-las as transformamos em equações diferenciais parciais com uso da bem estabelecida técnica das funções geratrizes [27]. Para tanto, introduzimos variáveis complexas $z, y \in[0,1] \mathrm{e}$ substituímos as probabilidades discretas por funções complexas definidas por:

$$
\alpha(z, y, t)=\sum_{n, m=0}^{\infty} \alpha_{n, m}(t) z^{n} y^{m}, \quad \beta(z, y, t)=\sum_{n, m=0}^{\infty} \beta_{n, m}(t) z^{n} y^{m}
$$


As funções discretas, $\alpha_{n, m}(t)$ e $\beta_{n, m}(t)$, são reobtidas tomando-se derivadas das funções complexas em Eq. (2.3), com relação à $z$ e $y$, e avaliando-as em $z=y=0$ :

$$
\begin{aligned}
\alpha_{n, m}(t) & =\left[\frac{1}{n ! m !} \frac{d^{n}}{d z^{n}} \frac{d^{m}}{d y^{m}} \alpha(z, y, t)\right]_{z=y=0} \\
\beta_{n, m}(t) & =\left[\frac{1}{n ! m !} \frac{d^{n}}{d z^{n}} \frac{d^{m}}{d y^{m}} \beta(z, y, t)\right]_{z=y=0}
\end{aligned}
$$

As equações diferenciais parciais resultantes são:

$$
\begin{aligned}
\frac{\partial \alpha(z, y, t)}{\partial t} & =(z-1)\left[k \alpha(z, y, t)-\rho \frac{\partial \alpha(z, y, t)}{\partial z}\right]-h \alpha(z, y, t)+f \beta(z, y, t) \\
& +(y-1)\left(z k_{p} \frac{\partial \alpha(z, y, t)}{\partial z}-\rho_{p} \frac{\partial \alpha(z, y, t)}{\partial y}\right) \\
\frac{\partial \beta(z, y, t)}{\partial t} & =(z-1)\left[\chi k \beta(z, y, t)-\rho \frac{\partial \beta(z, y, t)}{\partial z}\right]+h \alpha(z, y, t)-f \beta(z, y, t) \\
& +(y-1)\left(z k_{p} \frac{\partial \beta(z, y, t)}{\partial z}-\rho_{p} \frac{\partial \beta(z, y, t)}{\partial y}\right)
\end{aligned}
$$

que devem ser resolvidas sob a condição de que $\alpha(1,1, t)+\beta(1,1, t)=1$, para garantir a conservação de probabilidade. Os momentos da distribuição estatística, definidas pelas Eqs. (2.1) e (2.2), são obtidas calculando as derivadas, com relação à $z$ e $y$, das funções complexas em Eq. (2.3) e avaliando em $z=y=1$.

$$
\begin{aligned}
& \left\langle n_{\alpha}^{p} m_{\alpha}^{q}\right\rangle(t)=\sum_{n, m=0}^{\infty} n^{p} m^{q} \alpha_{n, m}(t)=\left(z \frac{d}{d z}\right)^{p}\left(y \frac{d}{d y}\right)^{q} \alpha(z, y, y), \\
& \left\langle n_{\beta}^{p} m_{\beta}^{q}\right\rangle(t)=\sum_{n, m=0}^{\infty} n^{p} m^{q} \beta_{n, m}(t)=\left(z \frac{d}{d z}\right)^{p}\left(y \frac{d}{d y}\right)^{q} \beta(z, y, t) .
\end{aligned}
$$




\section{Capítulo 3}

\section{Propriedades assintóticas do processo transcricional}

Neste capítulo, focamos atenção nas soluções estacionárias do processo de transcrição e suas características fundamentais. As propriedades transcricionais do sistema são obtidas somando sobre o número de proteínas $m$ as Eqs. (2.1) e (2.2) e assim, obtem se a distribuição de probabilidade marginal para o processo de transcrição ou, equivalentemente, colocando-se $y=1$ nas Eqs. (2.5) e (2.6) $)$.

\subsection{As equações e suas soluções estacionárias para a transcrição}

As equações para o processo transcricional, em seu limite assintótico, são obtidas colocando $y=1$ nas Eqs. (2.5) e (2.6). Obtém-se assim:

$$
(z-1)\left(k \alpha_{S}-\rho \frac{d \alpha_{S}}{d z}\right)-h \alpha_{S}+f \beta_{S}=0
$$

$\mathrm{e}$

$$
(z-1)\left(\chi k \beta_{S}-\rho \frac{d \beta_{S}}{d z}\right)+h \alpha_{S}-f \beta_{S}=0
$$


onde o índice $\mathrm{S}$, nas funções $\alpha(z)$ e $\beta(z)$, significa que a solução é estacionária. As equações acopladas Eqs. (3.1) e (3.2) são transformadas em uma única equação diferencial de segunda ordem substituindo-se

$$
\beta_{S}=\frac{1}{f}\left[\rho(z-1) \frac{d \alpha_{S}}{d z}-(z k-k-h) \alpha_{S}\right]
$$

na Eq. (3.2). A equação resultante em sua forma canônica é

$$
\frac{d^{2} \alpha_{S}}{d z^{2}}+p \frac{d \alpha_{S}}{d z}+q \alpha_{S}=0
$$

onde as funções $p$ e $q$ são dadas por

$$
\begin{aligned}
& p=\frac{(1-z)(1+\chi) k+\rho+h+f}{\rho(z-1)}, \\
& q=\frac{k^{2} \chi(z-1)-k(\rho+f+\chi h)}{\rho^{2}(z-1)} .
\end{aligned}
$$

As funções $p$ e $q$ têm pólo simples em $z=1$ e uma irregularidade em $z=\infty$, portanto, a solução geral é divergente em $z=1$. No entanto, uma solução particular regular é obtida e expressa em termos de funções hipergeométricas. De fato, introduzindo a variável

$$
\xi=\frac{k(\chi-1)(z-1)}{\rho}
$$

e realizando a transformação

$$
\alpha_{S}=\exp \left(\frac{k(z-1)}{\rho}\right) \tilde{\alpha}(\xi)
$$

obtém-se a equação de Kummer, em sua forma canônica

$$
\xi \frac{d^{2} \tilde{\alpha}}{d \xi^{2}}+(b+1-\xi) \frac{d \tilde{\alpha}}{d \xi}-a \tilde{\alpha}=0
$$

com os parâmetros

$$
\begin{gathered}
a=\frac{h}{\rho}, \\
b=\frac{h+f}{\rho} .
\end{gathered}
$$


A solução geral da Eq. (3.9) é a combinação linear das funções de Kummer do tipo M e do tipo U. A solução Kummer-U é irregular em $z=1(\xi=0)$, porém as funções de Kummer do tipo M são regulares em $z=1(\xi=0)$ e a solução para a componente $\alpha_{S}(z)$ é escrita em termos destas funções regulares

$$
\alpha_{S}(z)=\frac{b-a}{b} \exp \left(\frac{k(z-1)}{\rho}\right) M\left(a, b+1 ; \frac{k(\chi-1)(z-1)}{\rho}\right) ;
$$

uma equação para $\beta_{S}$ é obtida a partir da Eq. (3.3) usando-se a fórmula 13.4.10 da referência [28]:

$$
\beta_{S}(z)=\frac{a}{b} \exp \left(\frac{k(z-1)}{\rho}\right) M\left(a+1, b+1 ; \frac{k(\chi-1)(z-1)}{\rho}\right) .
$$

As constantes $(b-a) / b$ e $a / b$ foram calculadas impondo a normalização das soluções $(\alpha(1, t)+\beta(1, t)=1)$ e utilizando as relações de recorrência para as funções de Kummer [28]. Também pode se obter uma fórmula simples para a função geratriz da probabilidade total $\phi_{S}=\alpha_{S}+\beta_{S}$, usando a fórmula 13.4.3 da referência [28].

$$
\phi_{S}(z)=\alpha_{S}(z)+\beta_{S}(z)=\exp \left(\frac{k(z-1)}{\rho}\right) M\left(a, b ; \frac{k(\chi-1)(z-1)}{\rho}\right) .
$$

A eliminação analítica da componente irregular da solução geral da Eq. (3.9) mostra a grande vantagem em se introduzir as funções geratrizes para resolver as equações mestras Eqs. (2.1) e (2.2). Quando cálculos numéricos são realizados para se obter as amplitudes de probabilidade, esta componente irregular é responsável por instabilidades numéricas no algoritmo.

\subsection{O conteúdo biológico do modelo}

Esta seção é dedicada à interpretação biológica dos parâmetros $k, \rho, h$ e $f$ do modelo. Os parâmetros, $h$ e $f$, dependem das propriedades intrínsecas do gene, i.e., a afinidade do operador por uma proteína reguladora específica e também das condições do meio intracelular, i.e., concentração de proteínas reguladoras. No entanto, para um melhor 
entendimento do conteúdo biológico do modelo as propriedades intrínsecas do gene e as condições intracelulares foram desacopladas e reexpressas em novos parâmetros.

Para tanto, equações simples para as probabilidades de ocupação, $P_{\alpha}(t)$ e $P_{\beta}(t)$, de encontrarmos o gene livre ou reprimido por uma proteína ligada no sítio operador, respectivamente, foram obtidas fazendo $z=y=1$ nas Eqs. (2.5) e (2.6), dando:

$$
\begin{aligned}
& \frac{d P_{\alpha}(t)}{d t}=-h P_{\alpha}(t)+f P_{\beta}(t), \\
& \frac{d P_{\beta}(t)}{d t}=+h P_{\alpha}(t)-f P_{\beta}(t) .
\end{aligned}
$$

A solução do sistema é:

$$
\begin{aligned}
& P_{\alpha}(t)=\frac{f}{h+f}+e^{-(h+f) t}\left(P_{\alpha}(0)-\frac{f}{h+f}\right) . \\
& P_{\beta}(t)=\frac{h}{h+f}+e^{-(h+f) t}\left(P_{\beta}(0)-\frac{h}{h+f}\right) .
\end{aligned}
$$

A influência do meio sobre a transcrição do gene é medida pelas probabilidades assintóticas de encontrarmos o gene reprimido ou livre

$$
p_{\beta}=\frac{h}{h+f}, \quad p_{\alpha}=\frac{f}{h+f} .
$$

As informações relevantes com respeito às propriedades do switch no meio são especificadas por duas escalas de tempo

$$
T=\frac{1}{\rho}, \quad T_{S D}=\frac{1}{h+f} .
$$

A vida média da molécula de mRNA na célula é codificada em $T$ e é tipicamente da ordem de minutos. O significado do tempo de decaimento do switch $\left(T_{S D}\right)$ está relacionado com a evolução temporal do processo estocástico dinâmico. O tempo de decaimento do switch é uma propriedade intrínseca do gene, não dependendo das constantes de nascimento e morte, $k$ e $\rho$. O parâmetro adimensional

$$
\epsilon=\frac{T}{T_{S D}}=\frac{h+f}{\rho}
$$


decaimento relativo do switch, contém a informação sobre a flexibilidade do switch genético. Altos valores de $\epsilon$ correspondem a um switch rápido, ou seja, o switch alcança a configuração de equilíbrio antes da transcrição do gene ser estacionária. Como mostraremos na próxima sessão, o valor médio de cópias de mRNA não depende deste parâmetro mas o ruído é fortemente afetado por $\epsilon$.

No limite $p_{\beta}=0$ recuperamos o modelo apresentado em [22]. Neste caso, as soluções estacionárias das Eqs. (3.1) e (3.2) são: $\alpha_{S}(z)=\exp (N(z-1))$ e $\beta_{s}(z)=0$. O modo reprimido está desligado e $\alpha_{S}(z)$ é a função geratriz de uma distribuição de Poisson onde $N=k / \rho$ é o número médio de cópias de mRNA. Genes altamente reprimidos pertencem ao limite $p_{\beta}=1$, onde a transcrição é suprimida ou ocorre no modo reprimido $(\chi \neq 0)$. O parâmetro $\chi$ leva em consideração a possibilidade de uma pequena taxa de transcrição no (parcialmente) modo reprimido. Em resumo, $N$ mede a eficiência da transcrição. Um gene com grandes valores de $N$ produz mRNA em abundância na ausência de repressão podendo ter sua produção diminuída por proteínas reguladoras ou agentes externos para $\chi N$ partículas em média. Transcrições ineficientes como ocorrem em alguns genes da E. coli, por exemplo, corresponde a valores de $N$ por volta de um ou dois, enquanto que em transcrições abundantes $N$ aumenta uma ordem de magnitude. Os efeitos da concentração de proteínas ou algum outro fator repressor, são controlados por $p_{\beta}$, que pode ser fenomenologicamente relacionado à concentração de proteínas por uma função de Hill, por exemplo. O decaimento relativo do switch $(\epsilon)$ escala a capacidade do gene de flipar de uma configuração arbitrária para seu valor assintótico. As características relevantes das probabilidades podem ser obtidas por inspeção das funções geratrizes reescrevendo-as em termos destes novos parâmetros:

$$
\alpha_{S}(z)=p_{\alpha} \exp (N(z-1)) M\left(\epsilon p_{\beta}, \epsilon+1 ; N(z-1)(\chi-1)\right)
$$

para o estado ligado,

$$
\beta_{S}(z)=p_{\beta} \exp (N(z-1)) M\left(\epsilon p_{\beta}+1, \epsilon+1 ; N(z-1)(\chi-1)\right)
$$

para o estado desligado,

$$
\phi_{S}(z)=\exp (N(z-1)) M\left(\epsilon p_{\beta}, \epsilon ; N(z-1)(\chi-1)\right)
$$


para a probabilidade total.

Na ausência de um agente repressor $p_{\beta}=0\left(p_{\alpha}=1\right)$ a função geratriz do modo desligado é igual à zero $\left(\beta_{S}(z)=0\right)$ e a função geratriz do modo ligado reduz-se à função geratriz de um processo de Poisson $\left(\alpha_{S}(z)=\exp (N(z-1))\right)$ e assim, a distribuição de probabilidade que caracteriza o estado ligado será uma distribuição de Poisson onde o gene estará produzindo $N$ cópias de mRNA em média. Em geral, a função geratriz é uma série de potências em $N$, modulada por $\chi$ com coeficientes dependendo dos parâmetros de repressão $\left(p_{\beta}\right)$ e do decaimento relativo do switch $(\epsilon)$ via uma função de Pochhammer $\left((x)_{s}=x(x+1) \ldots(x+s-1)\right)$. Se o gene interage com um fator estocástico, como é caso de flutuações no número de proteínas devido a outro gene, os parâmetros $N, p_{\beta}$ e, eventualmente, $\epsilon$ devem ser considerados funções aleatórias do número de proteínas produzidas por este outro gene. O modelo apresenta duas fontes distintas para aumentar ou diminuir a transcrição. A eficiência da transcrição causada pela disponibilidade de polimerases afeta $N$, enquanto que a densidade de proteínas repressoras modifica $p_{\beta}$.

As probabilidades são obtidas tomando se derivadas sucessivas, com relação à $z$, das funções geratrizes, Eqs. (3.22), (3.23) e (3.24), e avliando-as em $z=0$. As derivadas são calculadas usando a regra de Leibniz e as fórmulas para derivadas das funções de Kummer (fórmula 13.4.9 referência [28]):

$$
\begin{gathered}
\alpha_{n}=p_{\alpha} N^{n} \frac{\exp (-N)}{n !} \sum_{s=0}^{n}\left(\begin{array}{l}
n \\
s
\end{array}\right)(\chi-1)^{s} \frac{\left(p_{\beta} \epsilon\right)_{s}}{(\epsilon+1)_{s}} M\left(p_{\beta} \epsilon+s, \epsilon+1+s ; N(1-\chi)\right), \\
\beta_{n}=p_{\beta} N^{n} \frac{\exp (-N)}{n !} \sum_{s=0}^{n}\left(\begin{array}{c}
n \\
s
\end{array}\right)(\chi-1)^{s} \frac{\left(p_{\beta} \epsilon+1\right)_{s}}{(\epsilon+1)_{s}} M\left(p_{\beta} \epsilon+1+s, \epsilon+1+s ; N(1-\chi)\right), \\
\phi_{n}=N^{n} \frac{\exp (-N)}{n !} \sum_{s=0}^{n}\left(\begin{array}{l}
n \\
s
\end{array}\right)(\chi-1)^{s} \frac{\left(p_{\beta} \epsilon\right)_{s}}{(\epsilon)_{s}} M\left(p_{\beta} \epsilon+s, \epsilon+s ; N(1-\chi)\right) .
\end{gathered}
$$

\subsection{Valores médios e ruído}

A forma analítica das funções geratrizes e as propriedades das funções de Kummer permitem que fórmulas simples para todos os momentos das distribuições de probabili- 
dade, sejam obtidas. Para tanto, calcula-se as derivadas das Eqs. (3.22), (3.23) e (3.24) em $z=1$, usando as Eqs. (2.7) e (2.8). O valor médio de mRNA, produzido em ambos os modos, na célula é

$$
\langle n\rangle=N\left(p_{\alpha}+\chi p_{\beta}\right) .
$$

Este é linear nos parâmetros $N$ (eficiência do gene) e em $p_{\beta}$ (agente repressor). O valor médio máximo de moléculas de mRNA é $N\left(p_{\beta}=0\right)$ e o mínimo é $\chi N\left(p_{\beta}=1\right)$. O decaimento relativo do switch $(\epsilon)$ não aparece no valor médio.

Fórmulas simples para os valores médio de moléculas de mRNA dos estados ligado e desligado, também são obtidas

$$
\begin{gathered}
\left\langle n_{\alpha}\right\rangle=N p_{\alpha}+\frac{N(\chi-1) \epsilon p_{\alpha} p_{\beta}}{1+\epsilon}, \\
\left\langle n_{\beta}\right\rangle=\chi N p_{\beta}-\frac{N(\chi-1) \epsilon p_{\alpha} p_{\beta}}{1+\epsilon} .
\end{gathered}
$$

Os efeitos da eficiência transcricional $(N)$ e do decaimento relativo do switch $(\epsilon)$ no ruído (flutuação no número de cópias de moléculas de mRNA produzidas) podem ser investigados a partir da variância

$$
\begin{aligned}
\left\langle n^{2}\right\rangle-\langle n\rangle^{2} & =N\left(p_{\alpha}+\chi p_{\beta}\right)+\frac{N^{2}(1-\chi)^{2} p_{\alpha} p_{\beta}}{1+\epsilon} \\
& =\langle n\rangle+\frac{N^{2}(1-\chi)^{2} p_{\alpha} p_{\beta}}{1+\epsilon}
\end{aligned}
$$

Nos dois limites $p_{\beta}=0$, ausência de repressão, e $p_{\beta}=1$, repressão total, o processo estocástico é poissoniano. O valor máximo do ruído é obtido impondo que a derivada da Eq. (3.31), com relação à $p_{\beta}$, seja nula, resultando em:

$$
\left(p_{\beta}\right)_{\max }=\frac{1}{2}-\frac{1}{2} \frac{1+\epsilon}{N(1-\chi)} .
$$

O desvio quadrático médio como função do parâmetro repressor $p_{\beta}$ para valores fixos de $N$ e de $\epsilon$ são exibidos na Fig. 3.1. As curvas correspondem a vários valores do decaimento relativo do switch $(\epsilon)$. Na Fig. 3.1(a) as flutuações para a transcrição copiosa do gene 
( $N$ grande) são apresentadas e na Fig. 3.1(b) está o caso onde a transcrição do gene é ineficiente ( $N$ pequeno). Para genes lentos ( $\epsilon$ pequeno) o ruído aumenta com o parâmetro $p_{\beta}$ até alcançar o valor máximo para $p_{\beta}=\left(p_{\beta}\right)_{\max }$, Eq. (3.32). Para um valor fixo de $p_{\beta}$ o ruído diminui para grandes valores de $\epsilon$.

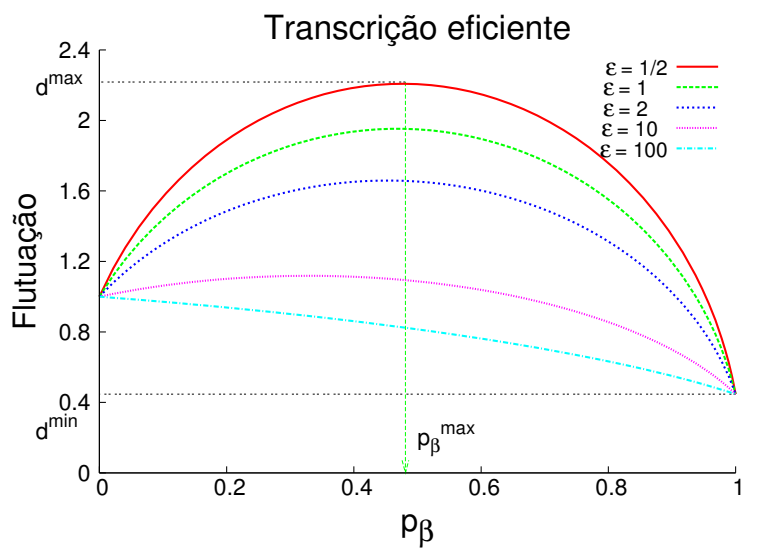

(a)

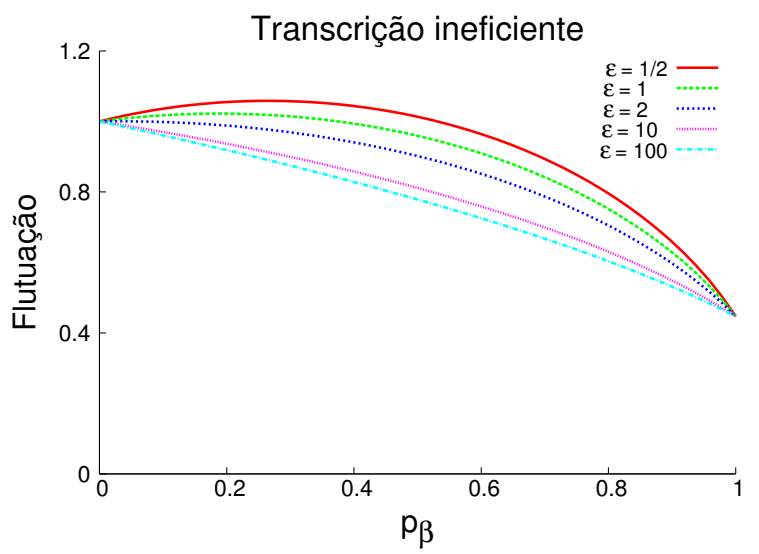

(b)

Figura 3.1: O desvio quadrático médio da população de mRNA é apresentado. Para tanto, calculamos o desvio quadrático médio como função do agente repressor $\left(p_{\beta}\right)$ usando a Eq. (3.31). A variação das flutuações como função do parâmetro de decaimento relativo do switch $(\epsilon)$ também é contemplada na figura. Na Fig. 3.1(a) uma transcrição altamente eficiente, correspondendo à $N=40$ e na Fig. 3.1(b) parâmetro de eficiência foi escolhido como sendo $N=4$ que corresponde a uma transcrição moderada. $\chi=1 / 5 \mathrm{em}$ abas as figuras.

Após atingir seu máximo as flutuações decrescem até o mínimo valor que corresponde à repressão total $\left(p_{\beta}=1\right)$. No caso em que o gene é lento (pequenos valores de $\epsilon$ ) e a transcrição é eficiente (grandes valores de $N$ ) o gene irá flipar entre as configurações ligado e desligado muitas vezes, causando um forte ruído na transcrição copiosa. Para se analisar o ruído do sistema pode-se utilizar tanto o desvio quadrático médio quanto o fator de Fano. O Fator de fano mede o desvio da distribuição de probabilidade de interesse com relação à distribuição de Poisson classificando o processo em questão como: poissoniana, sub-poissoniana ou super-poissoniana. No entanto, o fator de Fano não contempla a idéia intuitiva de largura da distribuição de probabilidade e por esta razão foi escolhido, aqui, o desvio quadrático médio para se analisar o ruído. Para grandes valores de $\epsilon$, correspondendo a switches rápidos, as flutuações parabólicas não atingirão o máximo, e sim, decrescerão monotonicamente. A repressão diminui o valor médio de mRNA transcritos e as flutuações simultaneamente. Inspecionando a Eq. (3.30) nota se a 
presença do fator $\epsilon+1$ em seu denominador que é o responsável pela atenuação do ruído. O processo de associação e dissociação de proteínas reguladoras com o sítio operador é, em geral, um processo mais rápido que o de degradação do mRNA, resultando em altos valores de $\epsilon$. A disparidade entre o tempo de vida do mRNA na célula e o tempo característico do processo de associação e dissociação de proteínas, garante baixas flutuações na transcrição. O aumento do ruído para genes transcritos de forma ineficiente é limitado pela presença de poucas cópias de mRNA na célula e cessa totalmente, para switches rápidos. O valor crítico para o decaimento relativo do switch é

$$
(\epsilon)_{\text {crit }}=N(1-\chi)-1
$$

A Eq. (3.33) foi obtida a partir da Eq. (3.32) impondo $\left(p_{\beta}\right)_{\max }=0$ o que garante um comportamento decrescente para as flutuações. Devemos ter em mente que a transcrição abundante de um gene requer a ação enzimática para eliminação de mensageiros não utilizados, o que causa um dispêndio de energia.

\subsection{Probabilidades}

Apesar do ruído ser completamente determinado apenas com o conhecimento dos dois primeiros momentos da distribuição de probabilidade, características fundamentais do sistema como a possibilidade de produção reprimida $(\chi \neq 0)$ só são possíveis de serem observadas com o conhecimento total da distribuição de probabilidade. A solubilidade do modelo nos permite investigar as probabilidades em termos dos parâmetros biofísicos do modelo.

As probabilidades como função da população de mRNA, para transcrição abundante do gene, são exibidas no conjunto de Figs. 3.2. No limite $p_{\beta}=0$ (sem repressão), $N=40$ cópias de mRNA são produzidas no estado estacionário. Uma pequena produção no caso em que há repressão, $\chi=1 / 5$, também é permitida. Na Fig. 3.2(a) o comportamento de um switch lento, $\epsilon=1 / 2$, é mostrado como função da atividade do repressor $p_{\beta}$. Na ausência de repressão um pico poissoniano aparece para valores de $n$ em torno de 40 . A 
presença de uma repressão moderada, $p_{\beta}=0.25$, tem três aspectos principais: reduz o máximo poissoniano, desloca o pico em direção a valores de $n$ pequeno e faz aparecer um pico secundário também em torno de valores de $n$ pequeno $(n \approx 8)$. Aumentando o valor de $p_{\beta}$ vemos o switch sendo desligado. A situação é revertida para repressão intermediária, $p_{\beta}=0.5$, o pico secundário já aparece dominante, indicando que a transcrição do gene ocorre predominantemente no estado desligado. Sob forte repressão, $p_{\beta}=0.75$, o pico do estado ligado é não poissoniano e é muito menor que o pico do estado desligado, e finalmente, sob repressão máxima, o gene encontra-se desligado e a transcrição ocorre no modo reprimido. O aumento do valor do decaimento relativo do switch $(\epsilon)$ irá favorecer a deslocalização da probabilidade, como mostrado na Fig. 3.2(b). As curvas que representam os modos livre $\left(p_{\beta}=0\right)$ e reprimido $\left(p_{\beta}=1\right)$ são as mesma que na Fig. 3.2(a) mas as curvas com valores intermediários do parâmetro repressivo estão amplamente deslocalizadas. A situação é ainda mais dramática se o gene é mais rápido, como mostrado na Fig. 3.2(c). Um plateau, com números da população de mRNA igualmente prováveis, aprece para repressão intermediária. O valor médio e as flutuações têm um significado limitado neste caso. Na Fig. 3.2(d), é visto o desaparecimento da estrutura de pico duplo para qualquer intensidade de repressão. Finalmente, nas Figs. 3.2(e) e 3.2(f), a probabilidade recupera o formato poissoniano e move adiabaticamente sob a ação da repressão. O desligamento do gene devido à repressão é mostrado na Fig. 3.3(a) para o caso de transcrição ineficiente $(N=4)$ e pequeno valor do decaimento relativo do switch $(\epsilon=1 / 2)$. O valor $\chi=1 / 50$, foi escolhido, portanto, não há transcrição residual no modo desligado. A curva que corresponde à $p_{\beta}=1$, incompleta no gráfico, representa a distribuição poissoniana reprimida e as outras curvas mostram a evolução da probabilidade com a diminuição da repressão. Os mesmos gráficos são exibidos na Fig. 3.3(b) porém, para o caso de switch rápido $(\epsilon=100)$. No conjunto de Figs. 3.4(a), 3.4(b) e 3.4(c) são apresentados gráficos tridimensionais das probabilidades como função de $\epsilon$ para regimes de repressão nula, moderada e total. Para repressão intermediária a variação de $\epsilon$ transforma a distribuição de pico duplo para pequeno $\epsilon$ em uma função não local até o comportamento tipo Poisson reaparecer para switches rápidos. 


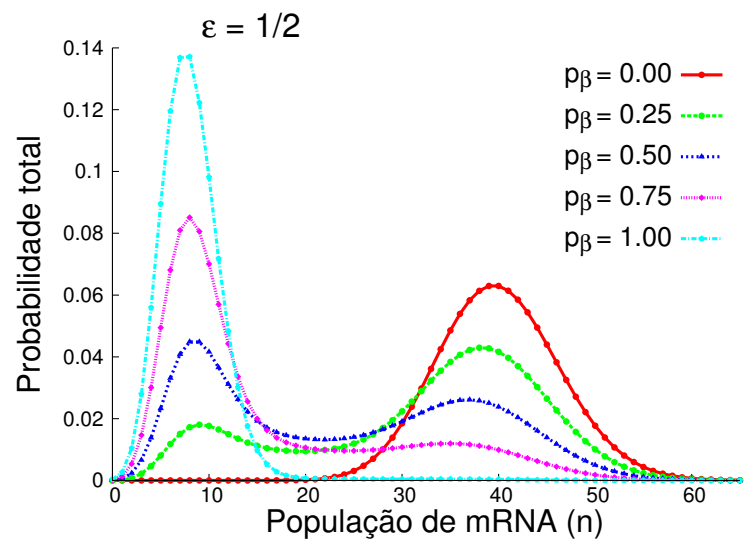

(a)

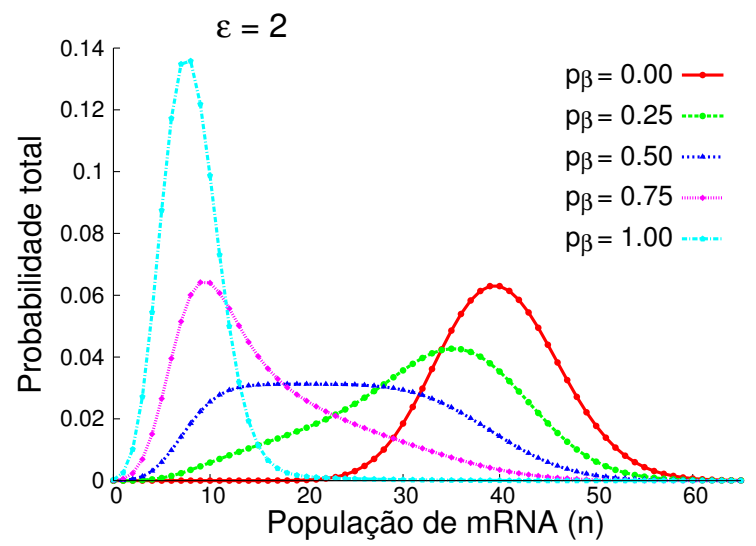

(c)

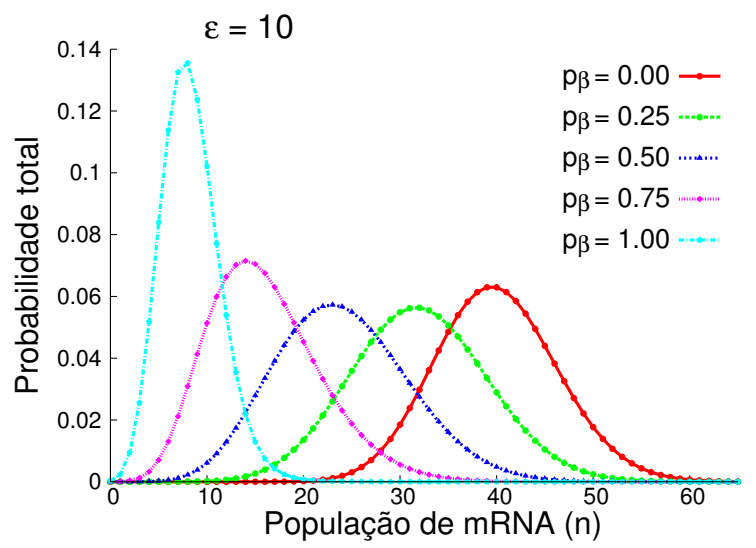

(e)

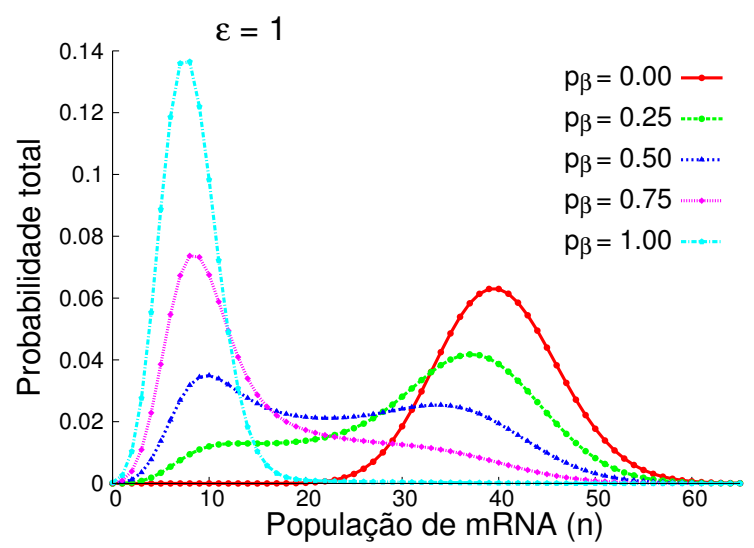

(b)

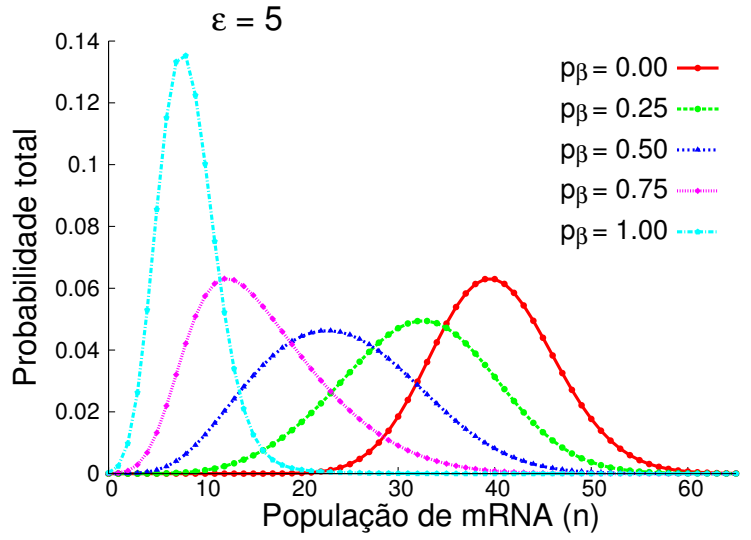

(d)

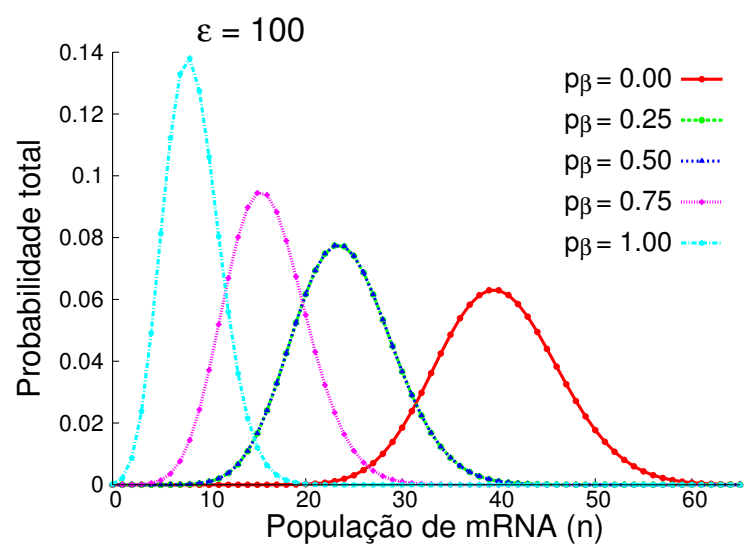

(f)

Figura 3.2: Neste conjunto de figuras cada gráfico corresponde a um diferente valor do parâmetro de decaimento relativo do switch $(\epsilon)$ e as curvas para vários valores do parâmetro repressivo $\left(p_{\beta}\right)$ são apresentadas. As curvas foram calculadas com a ajuda da Eq. (3.27). Na Fig. 3.2(a) um switch lento é mostrado com dois picos bem definidos. Na Figs. 3.2(b), 3.2(c), 3.2(d) e 3.2(e) a transição, entre uma estrutura de dois picos para uma estrutura poissoniana descrita na Fig. 3.2(f), é mostrada. Para todos os gráficos $N=40$ e $\chi=1 / 5$. 


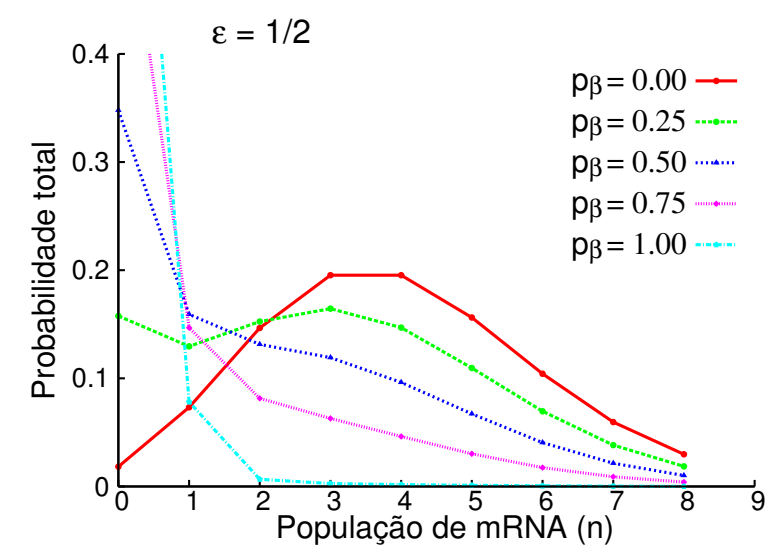

(a)

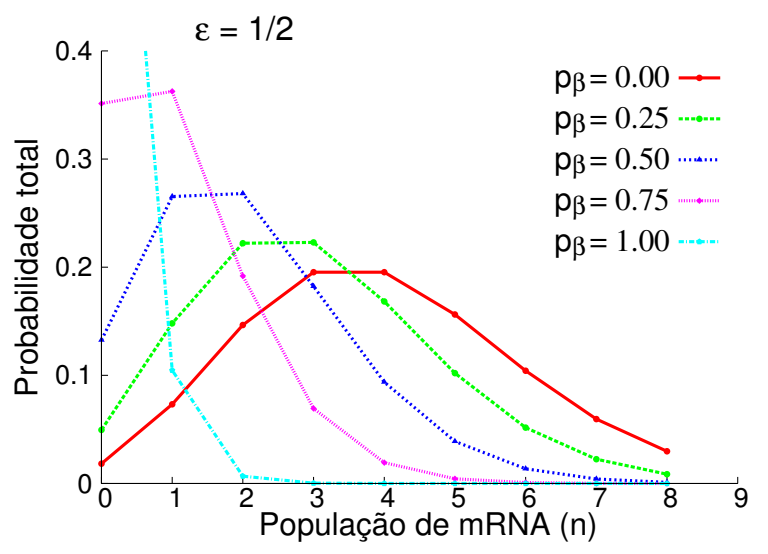

(b)

Figura 3.3: $\mathrm{O}$ mesmo que na Fig. 3.2 porém, para transcrição ineficiente $(N=4$ e $\chi=1 / 50)$. Somente os valore extremos do parâmetro de decaimento relativo do switch $(\epsilon)$ são apresentados. As curvas para $p_{\beta}=0$ e $p_{\beta}=1$ são as mesmas em ambos os casos. Para valores intermediários de $p_{\beta}$ as curvas diferem qualitativamente.

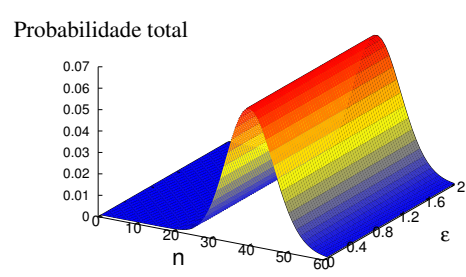

(a)

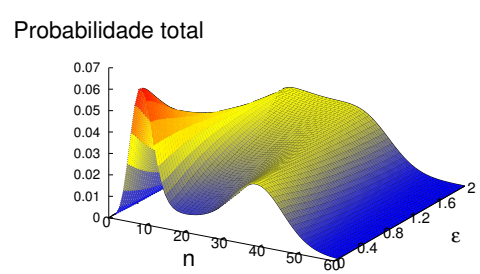

(b)

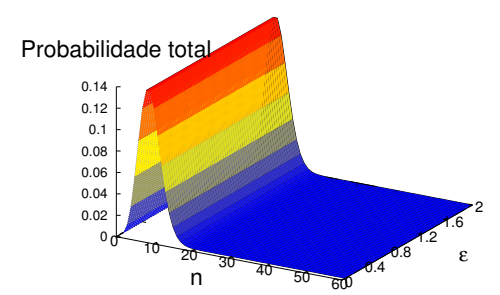

(c)

Figura 3.4: Nesse conjunto de figuras é apresentado o comportamento global da probabilidade total como função da população de mRNA, $n$, e do parâmetro de decaimento relativo do switch $(\epsilon)$. Na Fig. $3.4(a)$ não há repressão $\left(p_{\beta}=0\right)$ e uma distribuição de Poisson é observada para todos os valores de $\epsilon$. Na Fig. 3.4(c) repressão total $\left(p_{\beta}=1\right)$ com as probabilidades concentradas em torno de pequenos valores de $n$. Fig. 3.4(b) corresponde à situação intermediária com uma estrutura de dois picos para pequenos valores de $\epsilon$. 


\section{Capítulo 4}

\section{Dinâmica transcricional}

Neste capítulo, as propriedades dinâmicas do processo de transcrição são investigadas. Para tanto, faz-se $y=1$, nas Eqs. (2.5) e (2.6), divide-as por $\rho$ e reescreve-as em termos dos novos parâmetros do modelo, que foram apresentados e discutidos na seção 3.2 . Obtendo assim, o seguinte conjunto de equações diferenciais parciais:

$$
\begin{aligned}
& \frac{1}{\rho} \frac{\partial \alpha(z, t)}{\partial t}=(z-1)\left[N \alpha(z, t)-\frac{\partial \alpha(z, t)}{\partial z}\right]-p_{\beta} \epsilon \alpha(z, t)+p_{\alpha} \epsilon \beta(z, t) \\
& \frac{1}{\rho} \frac{\partial \beta(z, t)}{\partial t}=(z-1)\left[\chi N \beta(z, t)-\frac{\partial \beta(z, t)}{\partial z}\right]+p_{\beta} \epsilon \alpha(z, t)-p_{\alpha} \epsilon \beta(z, t) .
\end{aligned}
$$

\subsection{A solução dependente do tempo}

Para resolver as Eqs. (4.1) e (4.2) uma primeira mudança de variável foi realizada, fazendo

$$
\tau=\exp (-\rho t)
$$

resultando nas equações:

$$
\begin{aligned}
& -\tau \frac{\partial \alpha(z, t)}{\partial \tau}=(z-1)\left[N \alpha(z, t)-\frac{\partial \alpha(z, t)}{\partial z}\right]-p_{\beta} \epsilon \alpha(z, t)+p_{\alpha} \epsilon \beta(z, t) \\
& -\tau \frac{\partial \beta(z, t)}{\partial \tau}=(z-1)\left[\chi N \beta(z, t)-\frac{\partial \beta(z, t)}{\partial z}\right]+p_{\beta} \epsilon \alpha(z, t)-p_{\alpha} \epsilon \beta(z, t) .
\end{aligned}
$$


Uma segunda mudança de variáveis foi proposta,

$$
\begin{aligned}
& \mu=1+(z-1) \exp (-t \rho)=1+(z-1) \tau \\
& \nu=z
\end{aligned}
$$

e as Eqs. (4.4) e (4.5) tomam a forma:

$$
\begin{gathered}
(\nu-1)\left(N \alpha(\mu, \nu)-\frac{\partial \alpha(\mu, \nu)}{\partial \nu}\right)-p_{\beta} \epsilon \alpha(\mu, \nu)+p_{\alpha} \epsilon \beta(\mu, \nu)=0 \\
(\nu-1)\left(\chi N \beta(\mu, \nu)-\frac{\partial \beta(\mu, \nu)}{\partial \nu}\right)+p_{\beta} \epsilon \alpha(\mu, \nu)-p_{\alpha} \epsilon \beta(\mu, \nu)=0 .
\end{gathered}
$$

Este sistema de equações diferenciais parciais, Eqs. (4.7) e (4.8), tem a mesma estrutura que o sistema formado pelas Eqs. (3.1) e (3.2). A transformação de variáveis proposta na Eq. (4.6), teve como efeito, transformar as equações diferenciais parciais, que descrevem a dinâmica do processo de transcrição, deixando-as idênticas as equações que descrevem as propriedades assintóticas do mesmo processo. As soluções estacionárias foram obtidas na seção 3.1 e, portanto, realizando o mesmo procedimento que foi utilizado para se resolver as Eqs. (3.1) e (3.2), uma equação diferencial de segunda ordem para $\alpha(\mu, \nu)$ é escrita e posta na forma canônica da equação de Kummer e, portanto, a obtenção da solução geral para as Eqs. (4.7) e (4.8) é direta, dando:

$$
\begin{aligned}
& \alpha(\mu, \nu)=F(\mu) \alpha_{S}(\nu)+G(\mu) A(\nu), \\
& \beta(\mu, \nu)=F(\mu) \beta_{S}(\nu)+G(\mu) B(\nu) .
\end{aligned}
$$

Onde temos:

$$
\begin{aligned}
\alpha_{S}(\nu) & =p_{\alpha} \exp (N(\nu-1)) M(a, 1+b ; \xi), \\
A(\nu) & =-(1-b) \xi^{(-b)} \exp (N(\nu-1)) M(a-b, 1-b ; \xi), \\
\beta_{S}(\nu) & =p_{\beta} \exp (N(\nu-1)) M(1+a, 1+b ; \xi), \\
B(\nu) & =(1-b) \xi^{(-b)} \exp (N(\nu-1)) M(1+a-b, 1-b ; \xi) .
\end{aligned}
$$

Os parâmetros $a$ e $b$ são os mesmo que foram obtidos na seção 3.1 e, aqui, $\xi$ é uma 
função de $\nu$. Explicitamente, temos:

$$
\begin{aligned}
a & =p_{\beta} \epsilon, \\
b & =\epsilon, \\
\xi & =N(\chi-1)(\nu-1) .
\end{aligned}
$$

As funções $F(\mu)$ e $G(\mu)$ são constantes de integração do sistema, Eqs. (4.7) e (4.8), e serão calculadas a partir das condições inicias. Na seção 3.1 foi dito que a solução geral da equação de Kummer é uma combinação linear de funções de Kummer do tipo M e do tipo U. No entanto, existem oito soluções distintas para a equação hipergeométrica confluente (fórmulas 13.1.12 - 13.1.19 da referência [28]) onde nem todas são linearmente independentes entre si (o wronskiano das soluções da equação de Kummer é dado pelas fórmulas 13.1.20 - 13.1.26 da referência [28]). Portanto, para escrever a solução geral das Eqs. (4.7) e (4.8), foi escolhido o par de funções, linearmente independentes, dado pelas fórmulas 13.1 .12 e 13.1.13 da referência [28]. Tendo em mãos a solução geral para as funções geratrizes $\alpha(\mu, \nu)$ e $\beta(\mu, \nu)$ e utilizando as fórmulas 13.4.4 e 13.4.12 da referência [28], obtém se uma expressão para a função geratriz da probabilidade total,

$\phi(\mu, \nu)=\alpha(\mu, \nu)+\beta(\mu, \nu)=\exp (N(\nu-1))\left[F(\mu) M(a, b ; \xi)+G(\mu) \xi^{(1+b)} M(1+a-b, 2-b ; \xi)\right]$.

Reescrevendo o conjunto de equações em Eq. (4.9) de uma forma mais intuitiva, obtém se:

$$
\left[\begin{array}{l}
\alpha(\mu, \nu) \\
\beta(\mu, \nu)
\end{array}\right]=\left[\begin{array}{ll}
\alpha_{S}(\nu) & A(\nu) \\
\beta_{s}(\nu) & B(\nu)
\end{array}\right]\left[\begin{array}{l}
F(\mu) \\
G(\mu)
\end{array}\right]
$$

Resolvendo para $F(\mu)$ e $G(\mu)$ fica-se com:

$$
\left[\begin{array}{c}
F(\mu) \\
G(\mu)
\end{array}\right]=\frac{1}{\alpha_{S}(\nu) B(\nu)-A(\nu) \beta_{S}(\nu)}\left[\begin{array}{rr}
B(\nu) & -A(\nu) \\
-\beta_{s}(\nu) & \alpha_{S}(\nu)
\end{array}\right]\left[\begin{array}{c}
\alpha(\mu, \nu) \\
\beta(\mu, \nu)
\end{array}\right]
$$

onde a quantidade $\delta=\alpha_{S}(\nu) B(\nu)-A(\nu) \beta_{S}(\nu)$ é:

$$
\delta=(1-\epsilon)[N(\chi-1)(\nu-1)]^{(-\epsilon)} \exp (N(1+\chi)(\nu-1))
$$


Como dito acima, as funções $F(\mu)$ e $G(\mu)$, são calculadas a partir das condições iniciais do sistema. Para tanto, faz-se $t=0$, o que implica em $\tau=1$ (Eq. (4.3)), e então, nas variáveis $\mu$ e $\nu$ (Eq. (4.6) ), isso significa fazer $\mu=\nu$ na Eq. (4.14), dando:

$$
\begin{aligned}
F(\mu) & =\exp (-N \chi(\mu-1))\left[M(1+a-b, 1-b, \widetilde{\xi}) C_{1}(\mu)\right. \\
& \left.+M(a-b, 1-b, \widetilde{\xi}) C_{2}(\mu)\right]
\end{aligned}
$$

$\mathrm{e}$

$$
\begin{aligned}
G(\mu) & =\frac{\widetilde{\xi}^{(b)} \exp (-N \chi(\mu-1))}{(b-1)}\left[p_{\beta} M(1+a, 1+b, \widetilde{\xi}) C_{1}(\mu)\right. \\
& \left.-p_{\alpha} M(a, 1+b, \widetilde{\xi}) C_{2}(\mu)\right]
\end{aligned}
$$

onde $\widetilde{\xi}=N(\chi-1)(\mu-1)=N(\chi-1)(z-1) \tau$ e $C_{1}(\mu)$ e $C_{2}(\mu)$ são as condições iniciais.

Fazendo a transformação inversa e voltando para as variáveis $z$ e $\tau$, a solução geral para as funções geratrizes, $\alpha(z, \tau)$ e $\beta(z, \tau)$, fica:

$$
\begin{aligned}
& \left.\alpha(z, \tau)=P(z, \tau) C_{1}(z, \tau)+Q(z, \tau)\right) C_{2}(z, \tau), \\
& \beta(z, \tau)=S(z, \tau) C_{1}(z, \tau)+T(z, \tau) C_{2}(z, \tau) .
\end{aligned}
$$

Explicitamente, as funções $P(z, \tau), Q(z, \tau), S(z, \tau)$ e $T(z, \tau)$, são:

$$
\begin{aligned}
P(z, \tau) & =\exp (N(z-1)(1-\tau \chi)) \\
& \times\left[p_{\alpha} M(1+a-b, 1-b ; N \tau(\chi-1)(z-1)) M(a, 1+b ; N(\chi-1)(z-1))\right. \\
& \left.+p_{\beta} \tau^{(b)} M(1+a, 1+b ; N \tau(\chi-1)(z-1)) M(a-b, 1-b ; N(\chi-1)(z-1))\right] \\
Q(z, \tau) & =\exp (N(z-1)(1-\tau \chi)) \\
& \times p_{\alpha}[M(a-b, 1-b ; N \tau(\chi-1)(z-1)) M(a, 1+b ; N(\chi-1)(z-1)) \\
& \left.-\tau^{(b)} M(a, 1+b ; N \tau(\chi-1)(z-1)) M(a-b, 1-b ; N(\chi-1)(z-1))\right] ;
\end{aligned}
$$




$$
\begin{aligned}
S(z, \tau) & =\exp (N(z-1)(1-\tau \chi)) \\
& \times p_{\beta}[M(1+a-b, 1-b ; N \tau(\chi-1)(z-1)) M(1+a, 1+b ; N(\chi-1)(z-1)) \\
& \left.-\tau^{(b)} M(1+a, 1+b ; N \tau(\chi-1)(z-1)) M(1+a-b, 1-b ; N(\chi-1)(z-1))\right] ; \\
T(z, \tau) & =\exp (N(z-1)(1-\tau \chi)) \\
& \times\left[p_{\beta} M(a-b, 1-b ; N \tau(\chi-1)(z-1)) M(1+a, 1+b ; N(\chi-1)(z-1))\right. \\
& \left.+p_{\alpha} \tau^{(b)} M(a, 1+b ; N \tau(\chi-1)(z-1)) M(1+a-b, 1-b ; N(\chi-1)(z-1))\right] .
\end{aligned}
$$

Com a solução geral para $\alpha(z, \tau)$ e $\beta(z, \tau)$, e usando a Eq. (4.12), a função geratriz $\phi(z, \tau)$ para a probabilidade total fica:

$$
\begin{aligned}
\phi(z, \tau) & =\exp (N(z-1)(1-\tau \chi)) \\
& \times[(M(1+a-b, 1-b ; N \tau(\chi-1)(z-1)) M(a, b ; N(\chi-1)(z-1)) \\
& -\frac{p_{\beta} N(\chi-1)(z-1) \tau^{(b)}}{(1-b)} \\
& \times M(1+a, 1+b, N \tau(\chi-1)(z-1)) M(1+a-b, 2-b, N(\chi-1)(z-1))) C_{1}(z, \tau) \\
& +(M(a-b, 1-b ; N \tau(\chi-1)(z-1)) M(a, b ; N(\chi-1)(z-1)) \\
& +\frac{p_{\alpha} N(\chi-1)(z-1) \tau^{(b)}}{(1-b)} \\
& \left.\times M(a, 1+b, N \tau(\chi-1)(z-1)) M(1+a-b, 2-b, N(\chi-1)(z-1))) C_{2}(z, \tau)\right] .
\end{aligned}
$$

As condições iniciais foram escolhidas de tal maneira que, no instante de tempo $t=0$ (o que corresponde a $\tau=1$ ), o sistema está em um de seus estados estacionários, então;

$$
\begin{aligned}
& C_{1}(z, \tau)=\overline{p_{\alpha}} \exp (N(z-1) \tau) M\left(\overline{p_{\beta}} \epsilon, 1+\epsilon ; N \tau(\chi-1)(z-1)\right), \\
& C_{2}(z, \tau)=\overline{p_{\beta}} \exp (N(z-1) \tau) M\left(1+\overline{p_{\beta}} \epsilon, 1+\epsilon ; N \tau(\chi-1)(z-1)\right),
\end{aligned}
$$

onde $\overline{p_{\alpha}}$ e $\overline{p_{\beta}}$ são os parâmetros repressivos que carregam a informação a respeito da influência do meio sobre o gene no instante de tempo $t=0$, ou seja, especificados $\overline{p_{\alpha}}$ e $\overline{p_{\beta}}$ sabemos o modo de produção em que o gene se encontra no instante inicial. Por exemplo, $\overline{p_{\alpha}}=0\left(\overline{p_{\beta}}=1\right)$ implica que no instante $t=0$ o gene está desligado ou parcialmente reprimido $(\chi \neq 0)$. 


\subsection{Valor médio e ruído dependentes do tempo}

Com a função geratriz para a distribuição de probabilidade total calculada, os primeiros momentos dependentes do tempo foram obtidos através de derivadas da Eq. (4.21) usando as Eqs. (2.7) e (2.8). Sendo assim, o primeiro momento (valor médio de mRNA na célula) é:

$$
\langle n\rangle=N\left(p_{\alpha}+\chi p_{\beta}\right)+\frac{N(\chi-1)\left(\epsilon \tau-\tau^{\epsilon}\right)\left(\overline{p_{\alpha}} p_{\beta}-\overline{p_{\beta}} p_{\alpha}\right)}{(1-\epsilon)}
$$

e o segundo momento da distribuição,

$$
\begin{aligned}
\left\langle n^{2}\right\rangle & =\langle n\rangle+N(1+\tau(1-\chi)) \\
& \times\left[N\left(1+2 p_{\beta}(\chi-1)\right)+N \tau(\chi-1)\left(\frac{2\left(\epsilon-\tau^{\epsilon-1}\right)\left(\overline{p_{\alpha}} p_{\beta}-\overline{p_{\beta}} p_{\alpha}\right)}{(1-\epsilon)}+1\right)\right] \\
& +\frac{[N(\chi-1)]^{2}\left[2\left(\epsilon\left(p_{\beta}+\overline{p_{\beta}}\right)+1\right)\left(\overline{p_{\alpha}} p_{\beta}-\overline{p_{\beta}} p_{\alpha}\right)\right]}{(\epsilon+1)(\epsilon-1)} \tau^{\epsilon+1} \\
& -\frac{[N(\chi-1)]^{2}\left[2\left(1-\epsilon p_{\alpha}\right)\left(\overline{p_{\alpha}} p_{\beta}-\overline{p_{\beta}} p_{\alpha}\right)\right]}{(\epsilon-1)(\epsilon-2)} \tau^{\epsilon} \\
& +\frac{[N(\chi-1)]^{2}\left[\epsilon^{2}\left(\overline{p_{\beta}}+p_{\alpha}\right)^{2}-\epsilon\left(2 \bar{p}^{2}+\overline{p_{\beta}}+2 \bar{p}_{\beta} p_{\alpha}+3 p_{\alpha}\right)+2\right]}{(\epsilon-1)(\epsilon-2)} \tau^{2} \\
& +\frac{[N(\chi-1)]^{2}\left[\epsilon\left(\overline{p_{\beta}}+p_{\alpha}\right)-1\right] p_{\beta}}{(\epsilon-1)} \tau+\frac{[N(\chi-1)]^{2}\left[1+\epsilon p_{\beta}\right] p_{\beta}}{(\epsilon+1)} .
\end{aligned}
$$

Com estas quantidades em mãos, a dinâmica das flutuações do sistema foi obtida através do desvio padrão dado por:

$$
\delta=\left[\left\langle n^{2}\right\rangle-\langle n\rangle^{2}\right]^{1 / 2}
$$

O fator de fano, que mede o desvio de uma dada distribuição de probabilidade em relação à distribuição de Poisson, também foi obtido e tem a forma:

$$
\frac{(\delta)^{2}}{\langle n\rangle}=\frac{\left\langle n^{2}\right\rangle-\langle n\rangle^{2}}{\langle n\rangle} .
$$

O comportamento dinâmico do valor médio de mRNA, das flutuações na população de mRNA e do desvio da distribuição de Poisson, é observado no conjunto de gráficos apresentados na Fig. 4.1. Para tanto, $\tau$ foi substituído pela sua forma exponencial, Eq. (4.3), e $1 / \rho$ foi posto igual a 120 segundos. O parâmetro $N$, que mede a eficiência do gene foi escolhido igual a 40 e $\chi=1 / 5$. Como condição inicial foi posto $\overline{p_{\beta}}=0.9$ na Eq. (4.22), o que representa um gene predominantemente em seu estado desligado. 


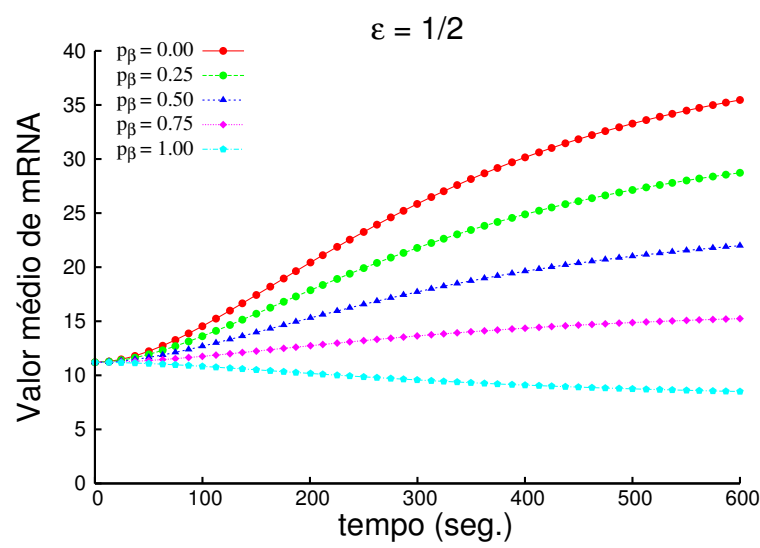

(a)

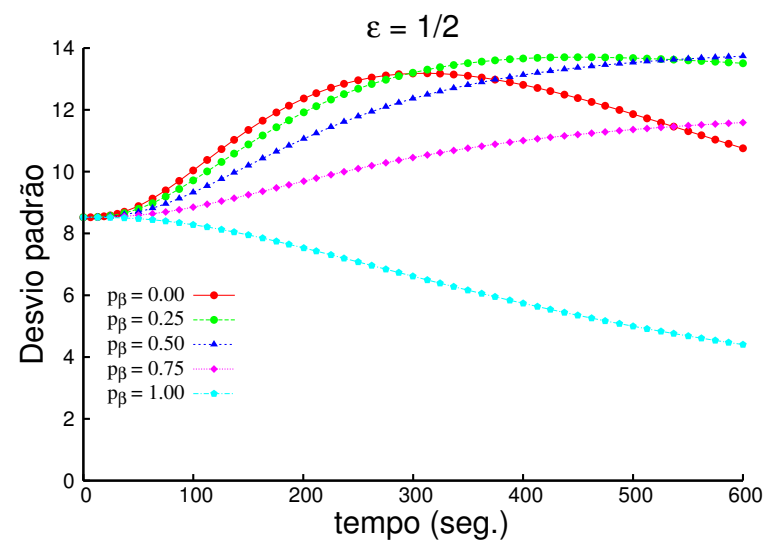

(c)

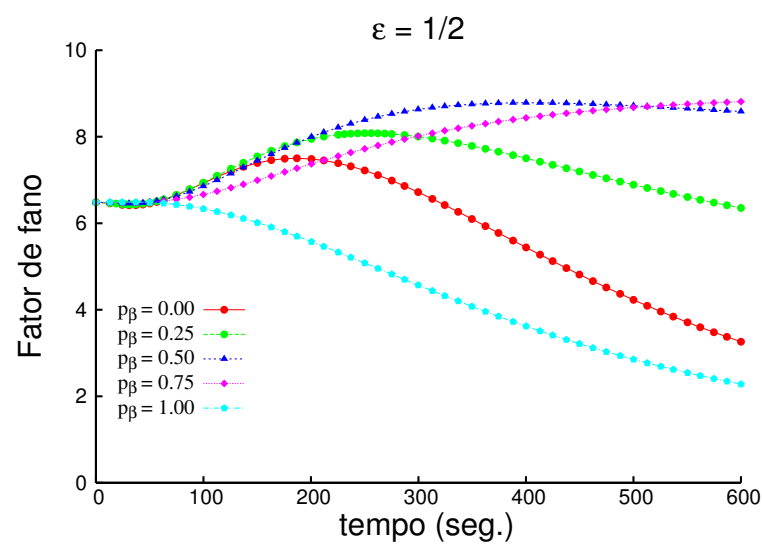

(e)

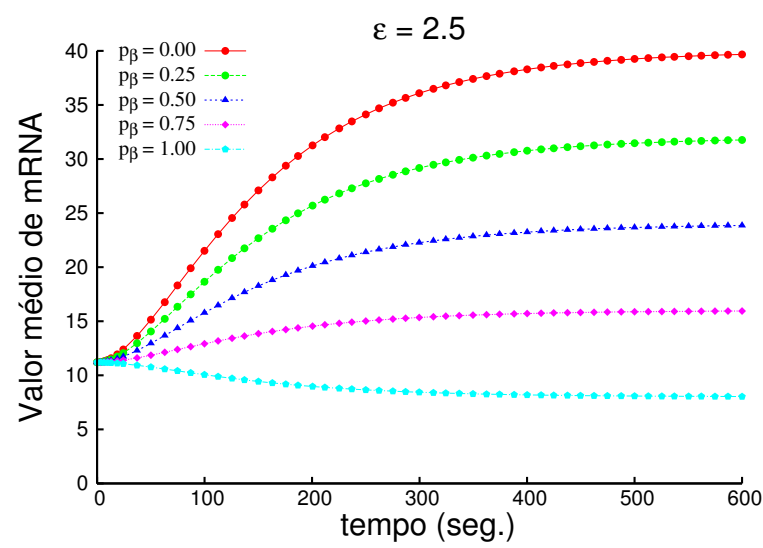

(b)

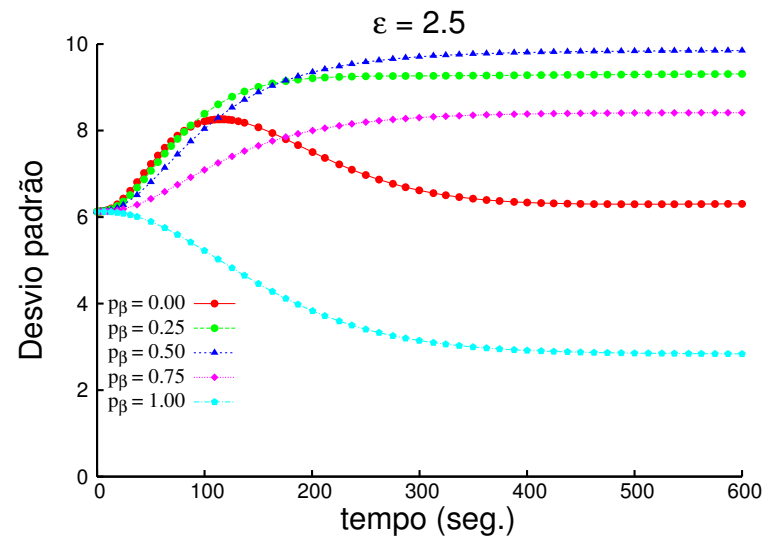

(d)

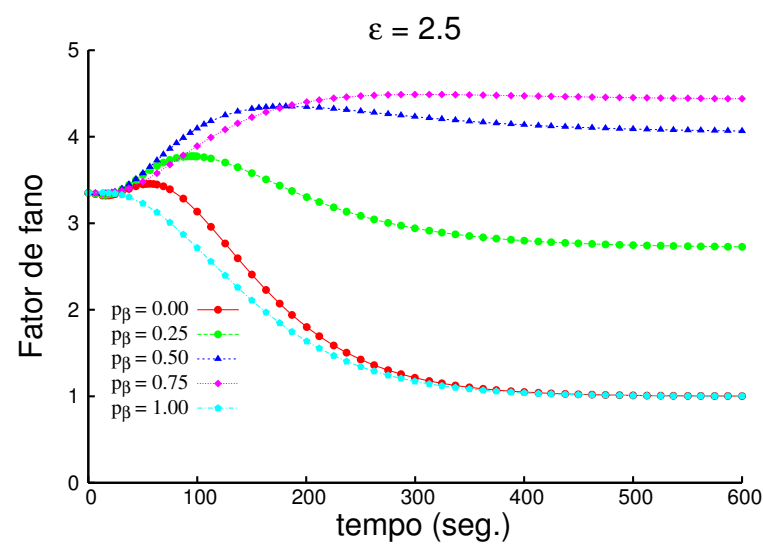

(f)

Figura 4.1: Neste conjunto de gráficos é apresentado o comportamento dinâmico do valor médio de mRNA, Figs. 4.1(a) e 4.1(b), das flutuações na população de mRNA, Figs. 4.1(c) e 4.1(d) e o desvio da distribuição de Poisson, Figs. 4.1(e) e 4.1(f), para vários valores do parâmetro repressivo assintótico $\left(p_{\beta}\right)$, como indicado na legenda dos gráficos. Como condição inicial foi feito $\overline{p_{\beta}}=0.9$ na Eq. (4.22). $N=40, \chi=1 / 5 \mathrm{e} 1 / \rho=120$ segundos para todos os gráficos. 
Os dois primeiros gráficos, Figs. 4.1(a) e 4.1(b), mostram a variação dinâmica do valor médio de mRNA em duas situações: switch lento $\epsilon=1 / 2$, (Fig. 4.1(a)), e switch rápido $\epsilon=2.5$, (Fig. 4.1(b) . Cada curva representa a evolução do valor médio de mRNA a partir de um mesmo estado inicial para diferentes estados assintóticos rotulados pelos diferentes valore de $p_{\beta}$, como mostra a legenda dos gráficos. As curvas com valores assintóticos de $p_{\beta}$, inferiores a $\overline{p_{\beta}}=0.9$, crescem monotonicamente até atingirem o estado estacionário. Isto mostra que o número médio de moléculas de mRNA aumenta à medida que a repressão diminui. A diferença entre um gene rápido ( $\epsilon$ grande) e um gene lento ( $\epsilon$ pequeno) é compreendida observando que as curvas na Fig. 4.1(b) atingem o estado estacionário ( $t \approx 300 \mathrm{seg}$.) antes que as curvas na Fig. 4.1(a).

A evolução das flutuações é exibida nos gráficos Fig 4.1(c) e 4.1(d), para os casos de switch lento e rápido, respectivamente. Para os valores intermediários do parâmetro repressivo assintótico $\left(p_{\beta}=0.25,0.50,0.75\right)$ as flutuações aumentam monotonicamente até atingirem seus estados estacionários. Para repressão total, $p_{\beta}=1$, a flutuação na população de mRNA decresce. Na ausência de repressão $\left(p_{\beta}=0\right)$ a curva apresenta um crescimento inicial até atingir o ponto de máxima flutuação e depois decresce até atingir seu valor assintótico.

O fator de fano, Figs 4.1(e) e 4.1(f), para os casos de switch lento e rápido, respectivamente, mostra que para valores intermediários do agente repressivo $\left(p_{\beta}=0.25,0.50,0.75\right)$ o processo é super-poissoniano $\left((\delta)^{2} /\langle n\rangle>1\right)$ e para os valores limites, $p_{\beta}=1$ (repressão total) e $p_{\beta}=0$ (ausência de repressão), a distribuição é poissoniana $\left((\delta)^{2} /\langle n\rangle=1\right.$ ) no regime assintótico.

\subsection{Probabilidades dependentes do tempo}

A partir das funções geratrizes para os modos ligado e desligado, Eqs. (4.18), e utilizando a Eq. (2.4) , fórmulas analíticas para distribuição de probabilidade para cada 
um dos modos são obtidas. Para o estado ligado, temos:

$$
\begin{aligned}
\alpha_{n}(\tau) & =\frac{[N(1+\tau(1-\chi))]^{n} \exp [-N(1+\tau(1-\chi))]}{n !} \\
& \times \sum_{r=0}^{n} \sum_{s=0}^{r} \sum_{p=0}^{s}\left(\begin{array}{l}
n \\
r
\end{array}\right)\left(\begin{array}{l}
r \\
s
\end{array}\right)\left(\begin{array}{l}
s \\
p
\end{array}\right) \frac{[N(\chi-1)]^{r} \tau^{s}}{[N(1+\tau(1-\chi))]^{r}} \\
& \times\left\{p_{\alpha} \overline{p_{\alpha}} M_{1}(r, s) M_{2}(s, p, \tau) M_{3}(p, \tau)+\tau^{\epsilon} p_{\beta} \overline{p_{\alpha}} M_{4}(r, s) M_{5}(s, p, \tau) M_{3}(p, \tau)\right. \\
& \left.+p_{\alpha} \overline{p_{\beta}} M_{1}(r, s) M_{4}(s, p, \tau) M_{6}(p, \tau)-\tau^{\epsilon} p_{\alpha} \overline{p_{\beta}} M_{4}(r, s) M_{1}(s, p, \tau) M_{6}(p, \tau)\right\},
\end{aligned}
$$

e para o estado desligado,

$$
\begin{aligned}
\beta_{n}(\tau) & =\frac{[N(1+\tau(1-\chi))]^{n} \exp [-N(1+\tau(1-\chi))]}{n !} \\
& \times \sum_{r=0}^{n} \sum_{s=0}^{r} \sum_{p=0}^{s}\left(\begin{array}{l}
n \\
r
\end{array}\right)\left(\begin{array}{l}
r \\
s
\end{array}\right)\left(\begin{array}{l}
s \\
p
\end{array}\right) \frac{[N(\chi-1)]^{r} \tau^{s}}{[N(1+\tau(1-\chi))]^{r}} \\
& +p_{\beta} \overline{p_{\alpha}} M_{5}(r, s) M_{2}(s, p, \tau) M_{3}(p, \tau)-\tau^{\epsilon} p_{\beta} \overline{p_{\alpha}} M_{2}(r, s) M_{5}(s, p, \tau) M_{3}(p, \tau) \\
& \times\left\{p_{\beta} \overline{p_{\beta}} M_{5}(r, s) M_{4}(s, p, \tau) M_{6}(p, \tau)+\tau^{\epsilon} p_{\alpha} \overline{p_{\beta}} M_{2}(r, s) M_{1}(s, p, \tau) M_{6}(p, \tau)\right\}
\end{aligned}
$$

As funções $M_{i}(i=1, \ldots, 6)$ são derivadas das funções de Kummer e dependem dos índices de soma $(r, s, p)$ via os parâmetros da Kummer e das funções de Pochhammer. Explicitamente, temos:

$$
\begin{aligned}
M_{1}(r, s) & =\frac{\left(\epsilon p_{\beta}\right)_{r-s}}{(1+\epsilon)_{r-s}} M\left(\epsilon p_{\beta}+r-s, 1+\epsilon+r-s ; N(1-\chi)\right), \\
M_{1}(s, p, \tau) & =\frac{\left(\epsilon p_{\beta}\right)_{s-p}}{(1+\epsilon)_{s-p}} M\left(\epsilon p_{\beta}+s-p, 1+\epsilon+s-p ; N \tau(1-\chi)\right), \\
M_{2}(s, p, \tau)= & \frac{\left(1+\epsilon p_{\beta}-\epsilon\right)_{s-p}}{(1-\epsilon)_{s-p}} M\left(1+\epsilon p_{\beta}-\epsilon+s-p, 1-\epsilon+s-p ; N \tau(1-\chi)\right), \\
M_{2}(r, s)= & \frac{\left(1+\epsilon p_{\beta}-\epsilon\right)_{r-s}}{(1-\epsilon)_{r-s}} M\left(1+\epsilon p_{\beta}-\epsilon+r-s, 1-\epsilon+r-s ; N(1-\chi)\right), \\
M_{3}(p, \tau)= & \frac{\left(\epsilon \overline{p_{\beta}}\right)_{p}}{(1+\epsilon)_{p}} M\left(\epsilon \overline{p_{\beta}}+p, 1+\epsilon+p ; N \tau(1-\chi)\right), \\
M_{4}(r, s)= & \frac{\left(\epsilon p_{\beta}-\epsilon\right)_{r-s}}{(1-\epsilon)_{r-s}} M\left(\epsilon p_{\beta}-\epsilon+r-s, 1-\epsilon+r-s ; N(1-\chi)\right), \\
M_{4}(s, p, \tau)= & \frac{\left(\epsilon p_{\beta}-\epsilon\right)_{s-p}}{(1-\epsilon)_{s-p}} M\left(\epsilon p_{\beta}-\epsilon+s-p, 1-\epsilon+s-p ; N \tau(1-\chi)\right), \\
M_{5}(s, p, \tau)= & \frac{\left(1+\epsilon p_{\beta}\right)_{s-p}}{(1+\epsilon)_{s-p}} M\left(1+\epsilon p_{\beta}+s-p, 1+\epsilon+s-p ; N \tau(1-\chi)\right), \\
M_{5}(r, s)= & \frac{\left(1+\epsilon p_{\beta}\right)_{r-s}}{(1+\epsilon)_{r-s}} M\left(1+\epsilon p_{\beta}+r-s, 1+\epsilon+r-s ; N(1-\chi)\right), \\
M_{6}(p, \tau)= & \frac{\left(1+\epsilon \overline{p_{\beta}}\right)_{p}}{(1+\epsilon)_{p}} M\left(1+\epsilon \overline{p_{\beta}}+p, 1+\epsilon+p ; N \tau(1-\chi)\right) .
\end{aligned}
$$


Os gráficos na Fig. 4.2 mostram a evolução temporal da distribuição de probabilidade total $\left(\phi_{n}(\tau)=\alpha_{n}(\tau)+\beta_{n}(\tau)\right)$ a partir de uma distribuição inicial quase poissoniana $\left(\overline{p_{\beta}}=0.9\right)$ onde o parâmetro que controla a eficiência do gene $(N)$ foi colocado igual a 40 e $\chi=1 / 5$. Novamente, $\tau$ foi substituído por sua forma exponencial, Eq. 4.3, e $1 / \rho=120$ segundos. Os dois gráficos têm como estado assintótico a distribuição de probabilidade rotulada pela ausência de repressão, $p_{\beta}=0$, como indicado no título de cada gráfico, sendo que a Fig. 4.2(a) corresponde à um gene lento $(\epsilon=1 / 2)$ e a Fig. 4.2(b) à um gene rápido $(\epsilon=5)$. Nesta figura observa-se a transição de um gene que no instante inicial está operando predominantemente em seu estado desligado $\left(\overline{p_{\beta}}=0.9\right)$ para o estado em que este se encotra em seu estado totalmente induzido $\left(p_{\beta}=0\right)$. Na Fig. 4.2(a) observa-se a evolução da distribuição de probabilidade, que no instante inicial é praticamente poissoniana, para uma distribuição que apresenta estrutura de dois picos $(t=300$ seg. $)$. Para tempos mais longos aproxima-se de sua forma assintótica que para o valor de $p_{\beta}=0$ é uma distribuição de Poisson com média igual à $N$, no entando para $t=700$ seg. nota-se um pequeno pico secundário para valores de $n \approx 8$, o que indica que o estado estacionário ainda não foi atingido. Na Fig. 4.2(b), vê-se a diminuição do pico inicial e seu deslocamento para valores maiores de $n$ atingindo o estado assintótico com um pico de, aproximadamente, metade da altura do pico inicial e uma distribuição mais deslocalizada.

No conjunto de gráficos, Figs. 4.3 e 4.4, a evolução temporal da distribuição de probabilidade total é apresentada para vários valores do parâmetro repressivo assintótico $\left(p_{\beta}\right)$, como mostra a legenda de cada gráfico, nos casos em que o gene é lento, Fig. 4.3 onde $\epsilon=1 / 2$, e em que o gene é rápido, Fig. 4.4 onde $\epsilon=5$. Nas Figs. 4.3 e 4.4, as condições iniciais e os prâmetros do modelo são os mesmas que foram utilizados na Fig. $4.2\left(\overline{p_{\beta}}=0.9, N=40, \chi=1 / 5\right.$ e $1 / \rho=120$ segundos $)$.

No primeiro gráfico da Fig. 4.3, a distribuição de probabilidade em $t=0$ é praticamente poissoniana e com um pico em $n \approx 8$. Isto corresponde a um gene parcialmente reprimido, $(\chi \neq 0)$, produzindo em torno de $\chi N=8$ moléculas de mRNA em média. Após 100 segundos, Fig. 4.3(b), os estados rotulados pelos diferentes valores do parâmetro de repressão assintótico $\left(p_{\beta}\right)$ começam a se separar. Na Fig. 4.3(c) a estrutura de dois picos 


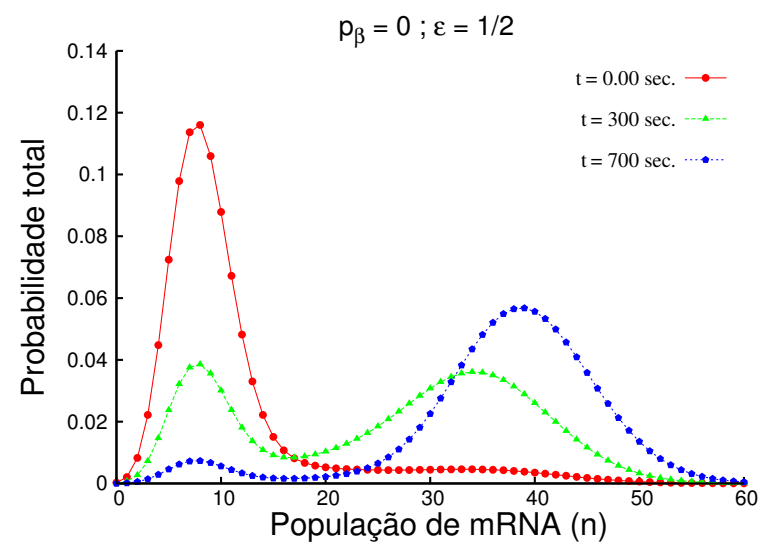

(a)

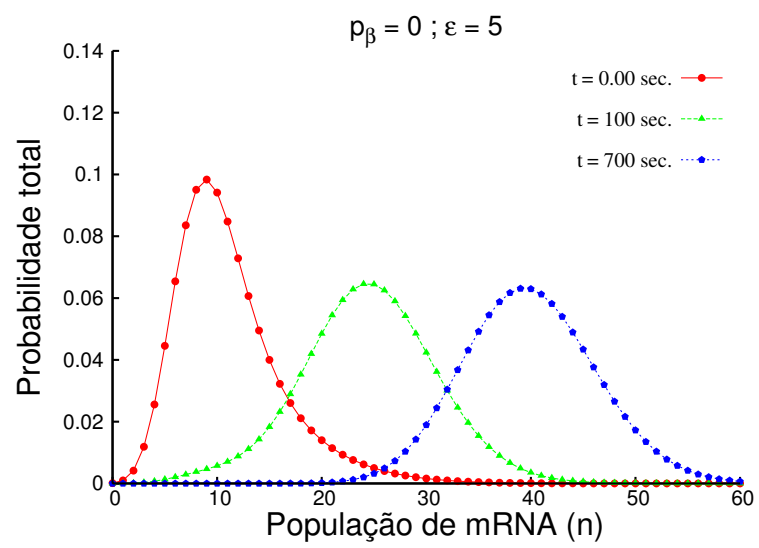

(b)

Figura 4.2: Neste conjunto de figuras a evolução dinâmica da distribuição de probabilidade total é contemplada. A condição inicial escolhida foi $\overline{p_{\beta}}=0.9$. Nas Figs. 4.2(a) e 4.2(b) a distrbuição inicial evolui até o estado assintótico rotulado por $p_{\beta}=0$, sendo que a primeira corresponde à um gene lento $\epsilon=1 / 2$ e a segunda à um gene rápido $\epsilon=5$. Para ambos os gráficos temos: $N=40, \chi=1 / 5$.

da distribuição de probabilidade já pode ser observada. Nos gráficos que correspondem a $t=500$ seg. e $t=700$ seg., Figs. 4.3(d) e 4.3(e), a estrutura de dois picos torna-se ainda mais evidente. Para $t=1000$ seg., Fig. 4.3(f), o gene encontra-se praticamente em seu estado assintótico, com exceção da curva rotulada por $p_{\beta}=0$. Esta curva apresenta um pico secundário residual para pequenos valores de $n$.

Os gráficos na Fig. 4.4 correspondem à evolução da distribuição de probabilidade que representam um gene rápido, $\epsilon=5$. Os parâmetros e as condições iniciais são os mesmos que os da Fig. 4.3. Neste conjunto de gráficos fica nítida a diferença entre um gene lento e um gene rápido. Na Fig. 4.4(c), onde $t=300$ seg., observa-se que a distribuição de probabilidade já está em seu estado estacionário, não alterando sua forma para tempos posteriores.

Os gráficos nas Figs. 4.3(f) e 4.4(c) podem ser comparados com os gráficos Figs. 3.2(a) $3.2(\mathrm{~d})$, respectivamente. Os últimos, apresentam as distribuições de probabilidade assintóticas para $\epsilon=1 / 2$ e $\epsilon=5$ que foram calculadas na seção 3.4 . 


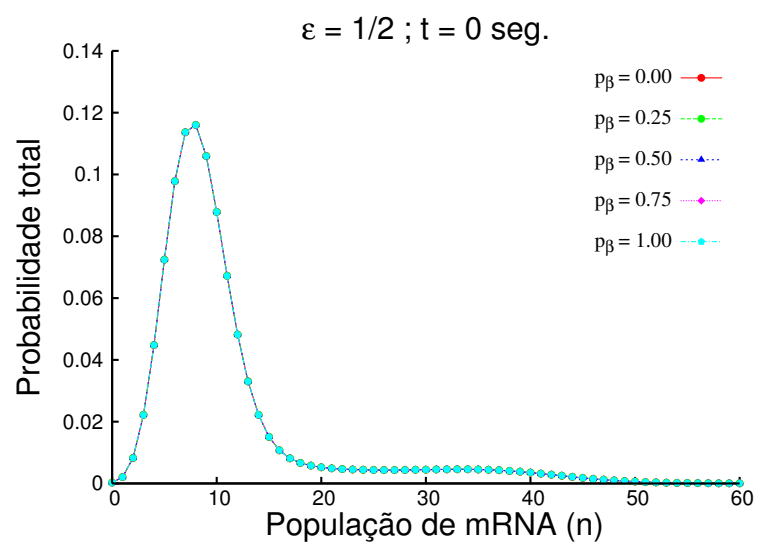

(a)

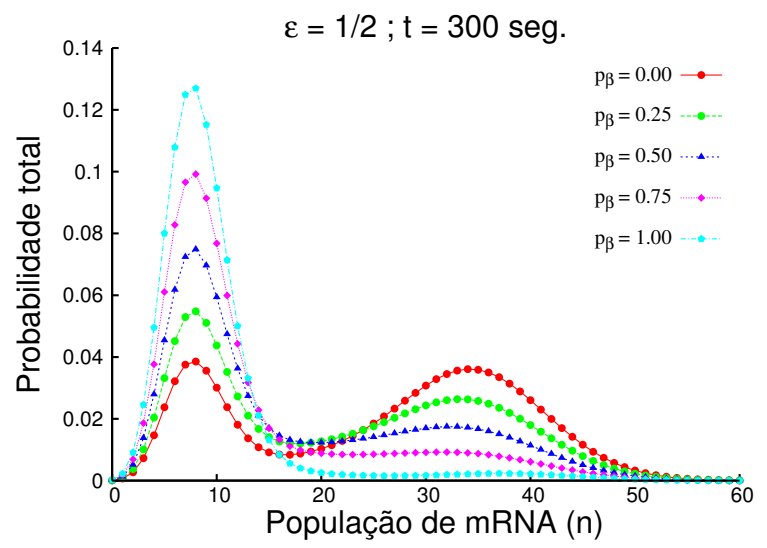

(c)

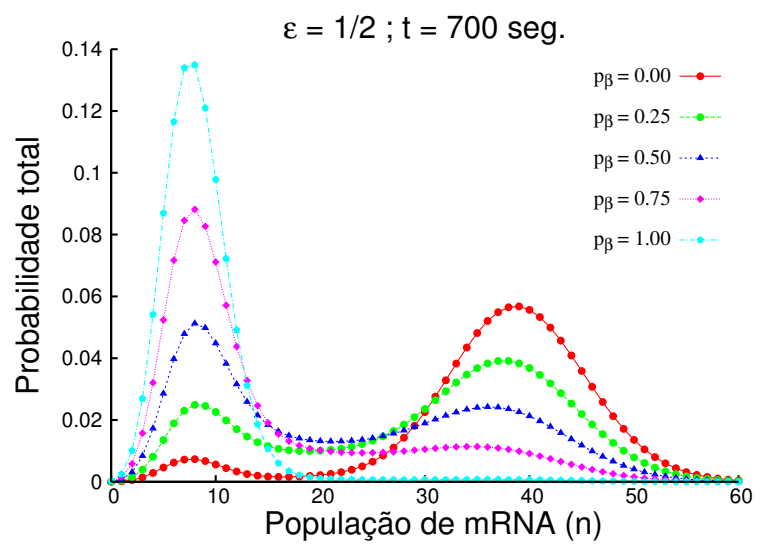

(e)

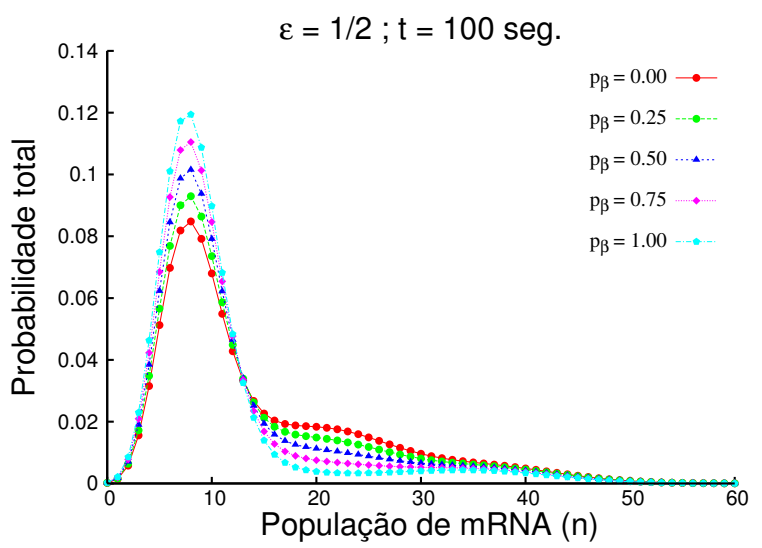

(b)

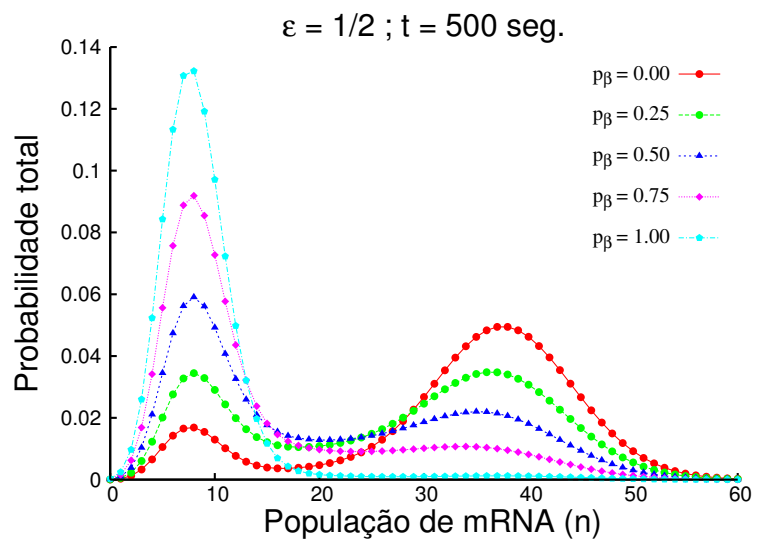

(d)

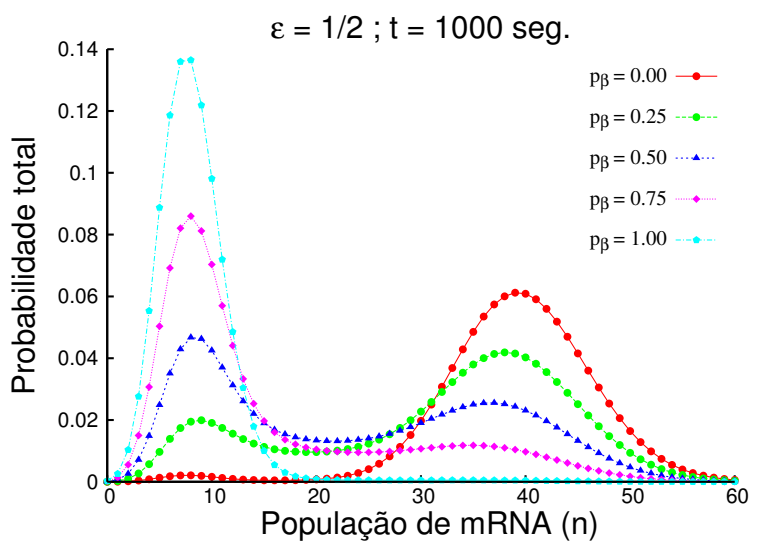

(f)

Figura 4.3: Neste conjunto de figuras é apresentada a evolução da distribuição de probabilidade total, a partir do estado inicial rotulado por $\overline{p_{\beta}}=0.9$, no caso em que o gene é lento, $\epsilon=1 / 2$. Cada curva representa a evolução da distribuição de probabilidade para um estado estacionário diferente, rotulado pelos distintos valores do parâmetro de repressão assintótico $p_{\beta}$, como indicado na legenda de cada gráfico. $N=40, \chi=1 / 5 \mathrm{e}$ $1 / \rho=120$ seg. para todos os gráficos. 


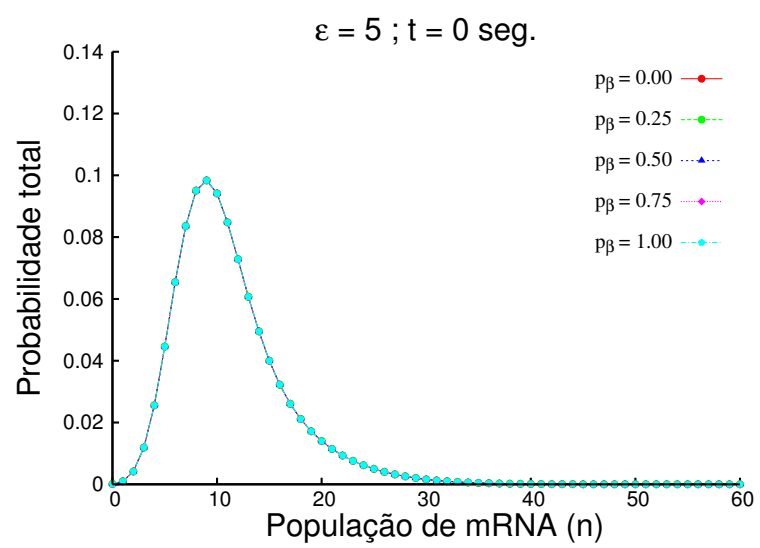

(a)

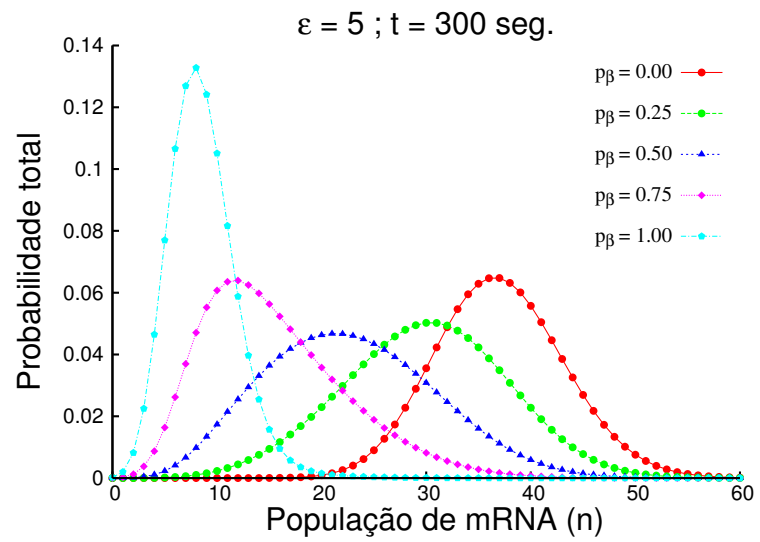

(c)

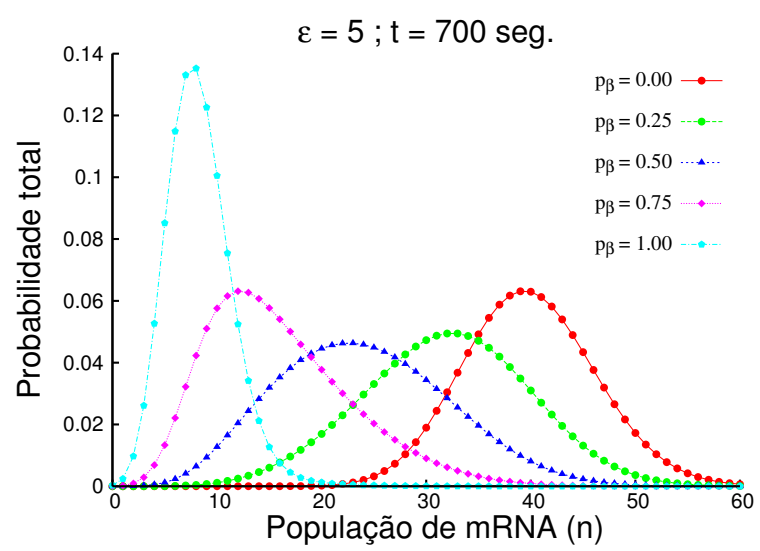

(e)

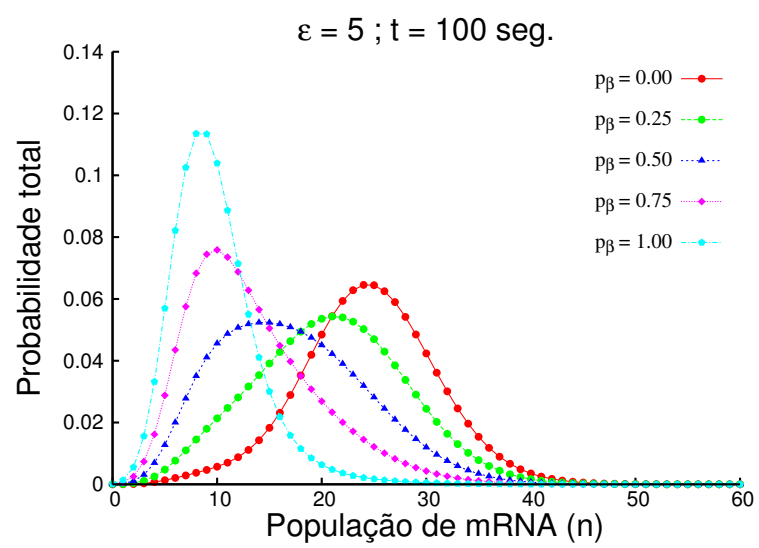

(b)

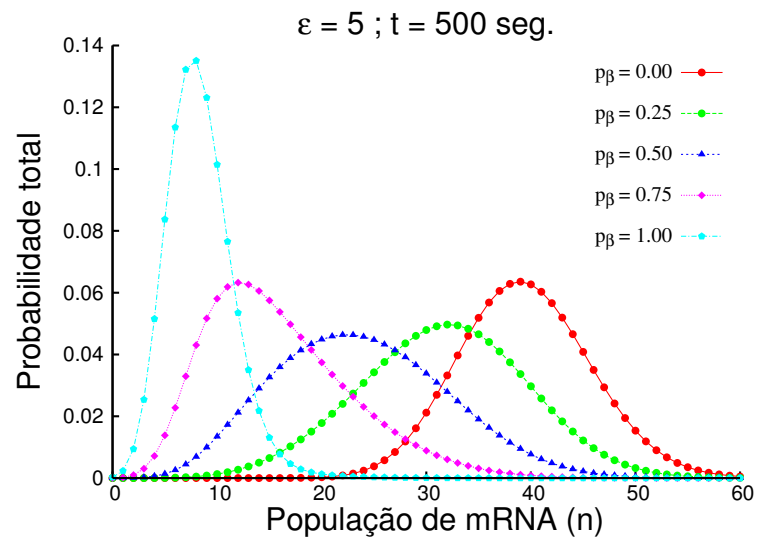

(d)

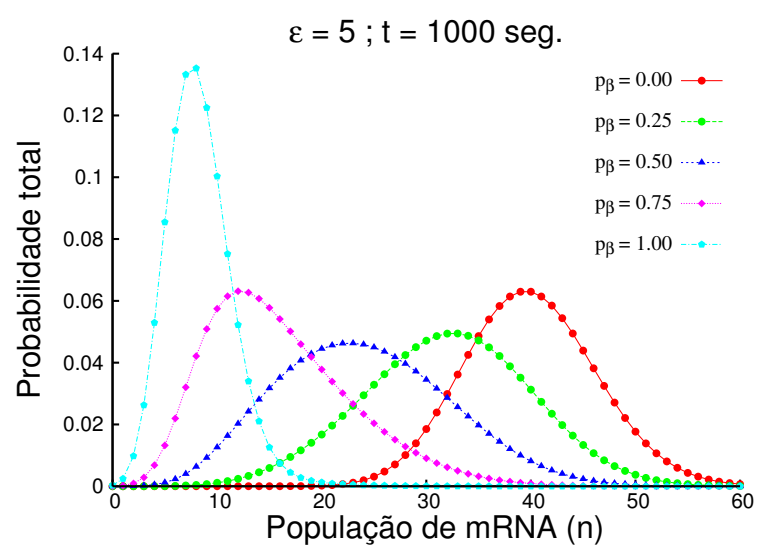

(f)

Figura 4.4: Os valores dos parâmetros e os estados inicias são os mesmo que na Fig. 4.3. Porém, neste conjunto de gráficos a evolução da distribuição de probabilidade é feita para o caso em que o gene é rápido, $\epsilon=5$. 


\section{Capítulo 5}

\section{O efeito do ruído transcricional na sintese proteica}

Os efeitos na concentração de proteínas devido às flutuações na transcrição são investigados considerando a forma estacionária das Eqs. (2.5) e (2.6). Dividindo estas equações por $\rho$ e reescrevendo-as em termos dos novos parâmetros do modelo obtidos na seção 3.2 , obtém se:

$$
\begin{aligned}
& (z-1)\left[N \alpha-\frac{\partial \alpha}{\partial z}\right]-p_{\beta} \epsilon \alpha+p_{\alpha} \epsilon \beta+(y-1)\left[\sigma z \frac{\partial \alpha}{\partial z}-\eta \frac{\partial \alpha}{\partial y}\right]=0, \\
& (z-1)\left[\chi N \beta-\frac{\partial \beta}{\partial z}\right]+p_{\beta} \epsilon \alpha-p_{\alpha} \epsilon \beta+(y-1)\left[\sigma z \frac{\partial \beta}{\partial z}-\eta \frac{\partial \beta}{\partial y}\right]=0 .
\end{aligned}
$$

Os novos parâmetros $\sigma$ e $\eta$ são iguais à $k_{P} / \rho$ e $\rho_{P} / \rho$, respectivamente, onde $k_{P}$ e $\rho_{P}$ são as taxas de nascimento e morte da reação efetiva da produção de proteínas. O acoplamento amplificativo [22,29] reproduz os "bursts" na produção de proteínas, que são observados experimentalmente. Para $p_{\beta}=0$ (ausência de repressão) a transcrição é Poissoniana e os resultados usais são reobtidos [22]. No entanto, no caso geral ambos os efeitos, o ruído induzido causado pelo acoplamento dos processos de transcrição e tradução, e o ruído devido à agentes repressivos, estão presentes no processo de síntese proteica. A obtenção das distribuições de probabilidade que descrevem o gene em seus estados ligado e desligado é, neste caso, bastante trabalhosa. No entanto, os momentos da 
distribuição podem ser obtidos recursivamente através de técnicas bem estabelecidas [27]. Assim, o valor médio para a população de proteínas é

$$
\langle m\rangle=\frac{\sigma N}{\eta}\left(\chi p_{\beta}+p_{\alpha}\right)
$$

O parâmetro adimensional $\eta$ é pequeno, tipicamente da ordem de $10^{-2}$, devido a discrepância entre as escalas de tempo para a transcrição e a tradução, ou seja, devido a diferença entre os tempos de vida da molécula de mRNA $(\approx$ minutos $)$ e das proteínas $(\approx$ horas). O parâmetro de eficiência do gene, $N$, é amplificado pelo fator $\sigma / \eta$. A variância do sistema é dada por:

$$
\left\langle m^{2}\right\rangle-\langle m\rangle^{2}=\langle m\rangle+\frac{\sigma^{2} N}{\eta(\eta+1)}\left(p_{\alpha}+\chi p_{\beta}+\frac{N p_{\alpha} p_{\beta}(\eta+\epsilon+1)\left((\chi-1)^{2}\right)}{(\eta+\epsilon)(\epsilon+1)}\right) .
$$

Os termos entre parênteses correspondem a ação de agentes externos. Se o gene está sobre a ação de agentes repressores $p_{\beta}$ irá aumentar e o valor médio de proteínas irá diminuir, de acordo com a Eq. (5.3). Em contraposição, quando o agente externo é um indutor, $p_{\beta}$ irá diminuir e a concentração média de proteínas irá aumentar. O gene é caracterizado no modelo por três freqüências ou escalas de tempo. A primeira é a taxa de degradação de mRNA $\rho$ que foi utilizada como a escala de tempo padrão. A segunda escala de tempo é definida pelo decaimento relativo do switch, expressa pelo parâmetro $\epsilon$. Esta segunda escala depende do gene em questão e é a menor escala de tempo do sistema, uma vez que o processo de associação e dissociação de proteínas reguladoras com o sítio operador é, em geral, um processo mais rápido que o de degradação de moléculas de mRNA. Finalmente, a última escala de tempo é expressa pela taxa de degradação de proteínas e é o maior tempo envolvido pois, tipicamente, o tempo de vida médio das proteínas é da ordem de horas. A discrepância entre estas escalas de tempo garantem um decréscimo no ruído global, o que leva a reprodução celular com precisão. Na Fig. 5.1 o desvio padrão é exibido em três casos distintos, com os parâmetros ajustados para que a concentração média de proteínas na célula $(\langle m\rangle=3200)$ fosse o mesmo em cada caso. A função monotonicamente decrescente mostra o comportamento da flutuação no caso em que o gene é ineficiente $(N=4)$ e rápido $(\epsilon=20)$. Na segunda curva, $\epsilon=5$, o ruído decresce continuamente e também representa uma função monotônica no parâmetro repressivo. Na curva que corresponde a $\epsilon=2$, as flutuações aumentam parabolicamente, 
para pequenos valores do parâmetro repressivo, até que a máxima flutuação é atingida decrescendo para grandes valores de $p_{\beta}$. O ponto de cruzamento das curvas, em torno de $p_{\beta} \approx 0.5$, corresponde a estados com mesmo número médio de proteínas, flutuações e repressão mas com diferentes velocidades de switch e diferentes taxas de produção.

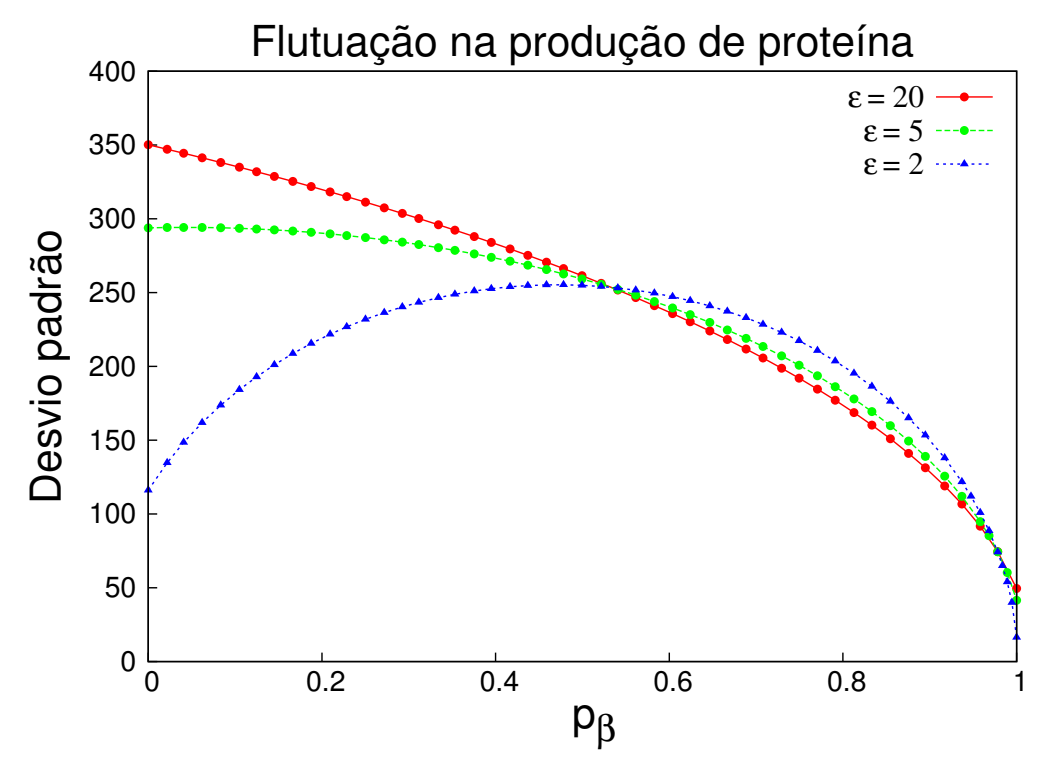

Figura 5.1: Desvio padrão na concentração de proteínas. Para todas as curvas $\eta=1 / 20$ e $\chi=1 / 50$. A curva com $\epsilon=20$ os parâmetros são: $k_{P}=39.60$ e $N=4$. A curva com $\epsilon=5, k_{P}=27.44$ e $N=5.8$ e a curva com $\epsilon=2, k_{P}=3.37$ e $N=47.5$.

Finalmente, é considerado um gene induzido por um agente externo. Este cenário, é obtido aumento o valor do parâmetro $p_{\alpha}$. Um exemplo concreto desta situação é o repressor tetraciclina sobre o controle do IPTG na E. coli. Esse gene foi usado como parte de uma cascata sintética de genes em experimentos recentes [14]. Uma rede de quatro genes foi elaborada e três deles foram monitorado por proteínas fluorescentes (cyan, yellow e red). Aumentando a concentração de IPTG diminui-se a repressão no primeiro gene e aumenta a concentração de CFP como pode ser observado na Fig. 1(b) da referência [14]. O ruído é exibido na Fig. 2(a). Neste modelo, as curvas correspondentes são Fig. 5.2(a), para a concentração de CFP e Fig. 5.2(b) para o respectivo ruído. Os parâmetros neste caso correspondem a um gene ineficiente $(N=1.20)$ e a um switch rápido $(\epsilon=30)$. Com o intuito de se comparar os resultados apresentados em [14], o parâmetro do modelo $p_{\alpha}$ foi relacionado com a concentração de indutor externo via uma função de Hill.

$$
p_{\alpha}=\frac{(c / A)^{\theta}}{1+(c / A)^{\theta}},
$$


onde $c$ é a concentração e $A$ um parâmetro.

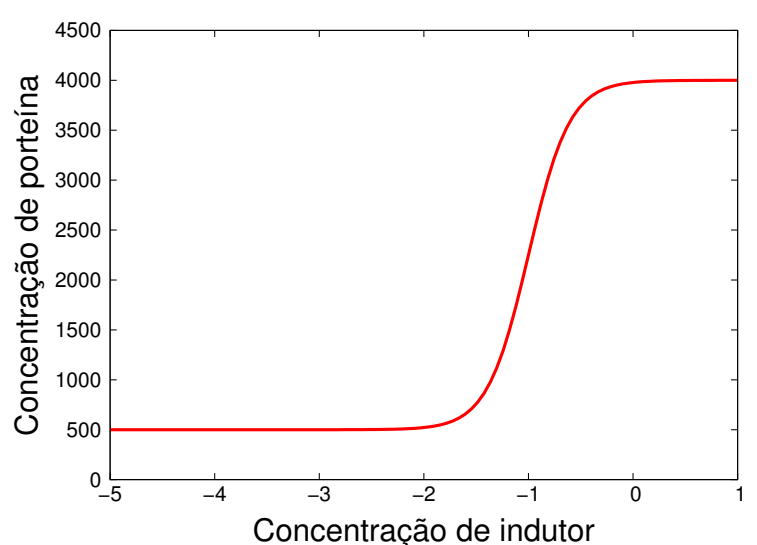

(a)

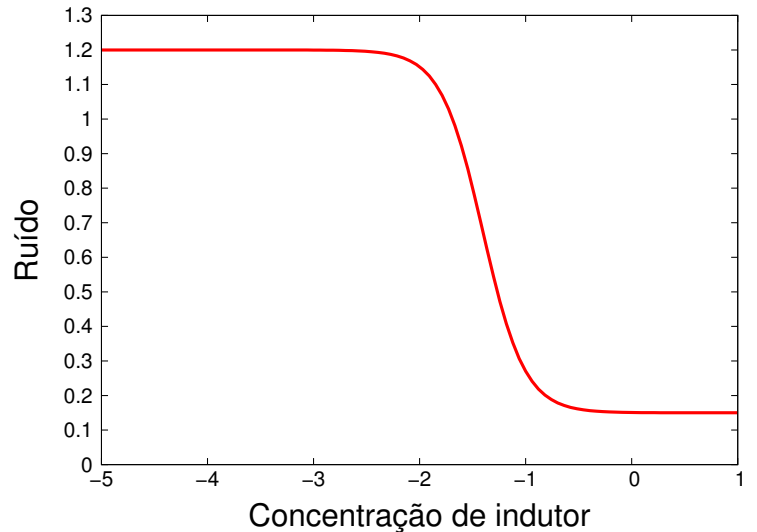

(b)

Figura 5.2: Na Fig. 5.2(a) a concentração de proteína é calculada como função da concentração de indutor em escala logarítmica. O valor dos parâmetros são: $\sigma=730, N=1.20$, $\eta=0.218, \chi=1 / 8, \epsilon=30, A=1 / 10$ e $\theta=2.2$. Na Fig. 5.2(b), o ruído como dado pela Eq. (5.4), é calculado como função da concentração de indutor em escala logarítmica. Figs. 5.2(a) e 5.2(b) devem ser comparadas com as Figs. 1(b) e 2(a) da referência [14, respectivamente.

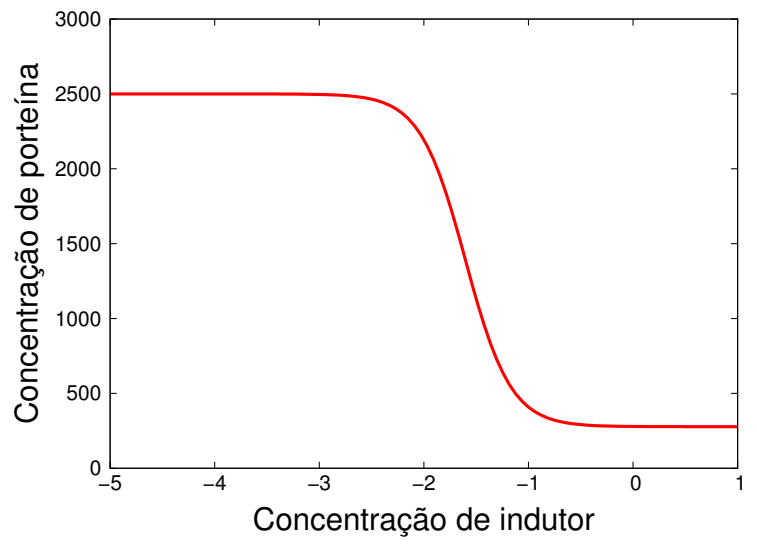

(a)

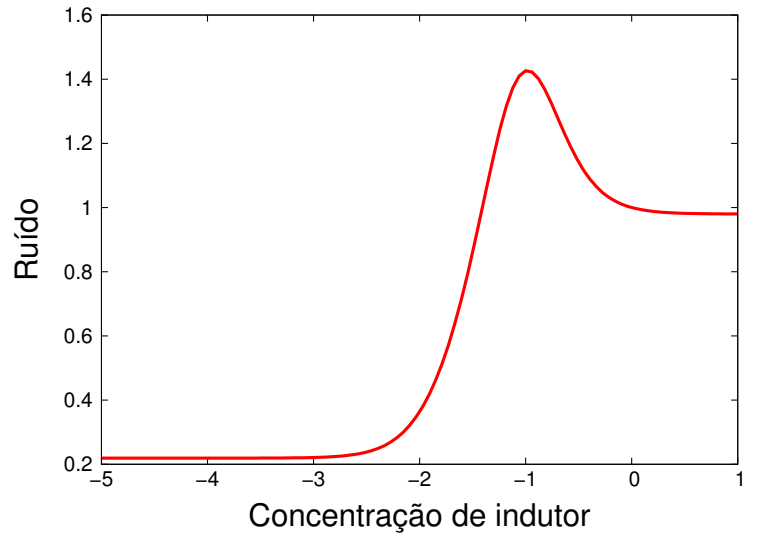

(b)

Figura 5.3: O mesmo que na Fig. 5.2 porém os parâmetros são: $\sigma=125, N=1$, $\eta=1 / 20, \chi=1 / 20, \epsilon=1 / 10, A=1 / 40$ e $\theta=2$. As Figs. 5.3(a) e 5.3(b) correspondem as Figs. 1(c) e 2(b) da referência [14], respectivamente.

Seguindo a referência [14] o ruído foi expresso através da seguinte quantidade:

$$
\Delta^{2}=\frac{\left\langle m^{2}\right\rangle-\langle m\rangle^{2}}{\langle m\rangle^{2}}
$$

A mesma análise foi realizada para o segundo gene que é apresentado nas Figs. 1(c) e 2(b) da referência [14] e aqui, correspondem as figuras 5.3(a) e 5.3(b), que são para um 
gene ineficiente $(N=1)$ e switch lento $(\epsilon=1 / 10)$. O experimento e os cálculos realizados na referência [14] levaram em consideração a interação entre os genes que compunham a rede. No entanto, mesmo o nosso modelo sendo para um único gene, é admirável a concordância entre o perfil da concentração e do ruído com os dados experimentais da referência [14]. O uso da função de Hill para relacionar o parâmetro $p_{\alpha}$ com o agente indutor, Eq. (5.5) é parcialmente responsável pelo comportamento na concentração de proteínas mostrado nas Figs. 5.2(a) e 5.3(a). No entanto, o comportamento do ruído com função da concentração de indutor, como pode ser visto nas Figs. 5.2(b) e 5.3(b), depende da Eq. (5.4) que é uma previsão do modelo. 


\section{Capítulo 6}

\section{Conclusões}

A diminuição do ruído em redes genéticas devido a ação de proteínas reguladoras é corroborada por alguns experimentos e também pela intuição comum de que repressão diminui as flutuações. No entanto, esta não é uma regra obrigatória. A presença de flutuações é governada pela eficiência transcricional de um gene, a presença de agentes repressores e, também, pelo decaimento relativo do switch que descreve a agilidade do gene em ir de uma configuração reprimida para uma onde este se encontra no estado livre. Essas componentes combinadas em um modelo estocástico simples para a transcrição de um gene em um ambiente repressivo, permite que condições para a ocorrência de ruído em uma rede genética elementar, sejam estabelecidas.

A transcrição ineficiente de genes é silenciosa (pequeno ruído) mesmo que o gene seja desligado lentamente. A presença de agentes repressores diminui as flutuações. No caso de genes rápidos as distribuições de probabilidade são do tipo Poisson e a alternância entre estado ligado e desligado irá causar pequenas variações no perfil das flutuações.

Em contraposição, no caso em que a transcrição do gene é eficiente as flutuações na população de mRNA serão muito significativas se o gene for lento. O ruído diminui com o aumento da repressão. No entanto, no caso de switches rápidos a variação do ruído entre os estados reprimindo e livre é mínima, revelando assim o papel fundamental do tempo relativo de switch na dinâmica do ruído.

As probabilidades microscópicas obtidas, devido a integrabilidade do processo de Mar- 
kov acoplado, mostra que as distribuições são não locais e estende-se por uma grande região da população de mRNA sob condições altamente ruidosas. A possibilidade de transcrição no estado parcialmente reprimido permitiu o surgimento de probabilidades com dois picos, um devido ao modo reprimido e outro ao modo livre.

Os dois mecanismos fundamentais que causam a diminuição na taxa de transcrição, a escassez de polimerase e a presença de agentes repressores, afetam as flutuações de maneiras distintas. No caso em que a população de polimerase não é abundante, o valor médio de mRNA irá diminuir homogeneamente com o parâmetro de eficiência do gene. Na presença de agentes repressores a dependência da flutuação no parâmetro que controla a repressão é parabólica.

A analiticidade das soluções dependentes do tempo permitiu que a evolução das distribuições de probabilidade fosse contemplada. A dinâmica do valor médio de moléculas de mRNA, das flutuações e do fator de fano foi obtida. O papel do parâmetro de decaimento relativo do switch, que contola a agilidade do gene em alternar de uma configuração reprimida para uma onde o gene está livre e vice-versa, evidenciou a diferença intrínseca de um gene que realiza switches de forma hábil e um gene que demora para atingir seu estado de equilíbrio.

O acoplamento entre os processos de transcrição e tradução, via o mecanismo amplificativo, reproduz os resultados experimentais observados ("bursts") na síntese de proteínas. O valor médio de proteínas e a flutuação na população proteica obtidos pelo modelo estão em concordância com resultados experimentais recentes.

O nosso modelo é mínimo no seguinte sentido: (i) é um modelo estocástico markoviano de dois estados totalmente solúvel; (ii) a introdução do segundo estado, que leva em conta a transcrição do gene em seu estado reprimido, fez emergir as duas escalas de tempo que regem o processo; (iii) os efeitos do ruído transcricional na síntese proteíca são contemplados via um acoplamento mínimo entre os preocessos de transcrição e tradução; (iv) a interação entre genes e a auto regulação de genes podem ser implementadas no nosso modelo. 


\section{Referências Bibliográficas}

[1] PTASHnE, M. A Genetic Switch: Phage $\lambda$ and Higher Organisms. Cambridge, Cell Press/Blackwell, 1992.

[2] MONOD, J.; JACOB, F. Genetic regulatory mechanisms in synthesis of protein. J. Mol. Biol., v. 3, p. 318-356, 1961.

[3] ACKERS, G.K.; et al. Quantitative model for gene regulation by $\lambda$ phage repressor Proc. Natl. Acad. Sci. USA, v. 79, p. 1129-1133, 1982.

[4] BECSKEI, A.; SERRANO, L. Engineering stability in gene networks by autoregulation. Nature, v. 405, p. 590-593, 2000.

[5] BERG, O.G. A model for the statistical fluctuations of protein number in a microbiol population. J. Theor. Biol., v. 71, p. 587-603, 1978.

[6] BHALLA, U.S.; IYENGAR, R. Emergent properties of networks of biological signaling pathways. Science, v. 283, p. 381-387, 1999.

[7] COOK, D.L.; et al. Modeling stochastic gene expression: Implications for haploinsufficiency. Proc. Natl. Acad. Sci., v. 95, p. 15641-15646, 1998.

[8] VON DASSOW, G.; et al. The segment polarity network is a robust developmental module. Nature, v. 406, p. 188-192, 2000.

[9] GILLESPIE, D.T.J. Exact stochastic simulation of coupled chemical reactions. J. Phys. Chem., v. 81, p. 2340-2361, 1977.

[10] KENNELL, D.; RIEZMAN, H. Transcription and translation initiation frequencies of the escherichia coli lac operon. J. Mol. Biol., v. 114, p. 1-21, 1977. 
[11] KO, M.S.H. A stochastic model for gene induction J. Theor. Biol., v. 153, p. 181-192, 1991.

[12] VAN DE PUTTE, P.; GOOSEN, N. DNA inversions in phages and bacteria. Trends Genet., v. 8, p. 457-462, 1992.

[13] SIEGELE, D.A.; HU, J.C. Gene expression from plasmids containing the araBAD promoter at subsaturating inducer concentrations represents mixed populations. Proc. Natl. Acad. Sci.USA, v. 94, p. 8168-8172, 1997.

[14] PEDRAZA J.M.; VAN OUDENAARDEN, A. Noise propagation in gene networks. Science, v. 307, p. 1965-1969, 2005.

[15] McADAMS, H.H.; ARKIN, A. It's a noisy business! Genetic regulation at the nanomolar scale. Trends Genet., v. 5, p. 65-69, 1999.

[16] McADAMS, H.H.; ARKIN, A. Stochastic mechanisms in gene expression Proc. Natl. Acad. Sci. USA, v. 94, p. 814-819, 1997.

[17] GARDNER, T.S.; et al. Construction of genetic toggle switch in Escherichia coli. Nature, v. 403, p. 339-342, 2000.

[18] HASTY, J.; et al. Noise-based switches and amplifiers for gene expression. Proc. Natl. Acad. Sci. USA, v. 97, p. 2075-2080, 2000.

[19] BLAKE, W.J.; et al. Noise in eukaryotic gene expression. Nature, v. 422, p. 633-637, 2003.

[20] PAULSSON, J. Stochastic focusing: Fluctuation-enhanced sensitivity of intracellular regulation. Proc. Natl. Acad. Sci. USA, v. 97, p. 7148-7153, 2000.

[21] ELOWITZ, M.B.; LEIBLER, S. A synthetic oscillatory network of transcriptional regulators. Nature, v. 403, p. 335-338, 2000.

[22] THATTAI, M.; VAN OUDENAARDEN, A. Intrinsic noise in gene regulatory networks. Proc. Natl. Acad. Sci. USA, v. 98, p. 8614-8619, 2001. 
[23] OZBUDAK, E.M.; et al. Regulation of noise in the expression of single gene. Nature Genet., v. 31, p. 69-73, 2002.

[24] SASAI, M.; WOLYNES, P.G. Stochastic gene expression as a many-body problem. Proc. Natl. Acad. Sci. USA, v. 100, p. 2374-2379, 2003.

[25] WALCZAK, A.M.; et al. Self-consistent proteomic field theory of stochastic gene switches. Biophys. J., v. 88, p. 828-850, 2005.

[26] HORNOS, J.E.M.; et al. Self-regulating gene: An exact solution. Phys. Rev. E, v. 72, p. 051907, 2005.

[27] VAN KAMPEN, N.G. Stochastic Processes in Physics and Chemistry. Amsterdam, North-Holland, 1992.

[28] ABRAMOWITZ, A.; STEGUN, I. A. Handbook of mathematical functions with formulas, graphs and mathematical tables, Nat. Bur. Standards Appl. Series, 55, U.S. Government Printing Office, Washington, D.C. (paperback edition published by Dover, New York), 1964.

[29] PAULSSON, J. Summing up the noise in gene networks. Nature, v. 427, p. 415-418, 2004. 